\title{
TÜRK VE ABD HUKUKUNDA KAMUYU AYDINLATMA BELGELERINDEN DOĞAN HUKUKİ SORUMLULUKTA ZARARIN DOĞDUĞU AN
}

\author{
Nevin MERAL*
}

\section{$\ddot{O} Z$}

Kamuyu aydınlatma belgelerinden doğan hukuki sorumluluğun unsuru olarak zararın incelendiği bu çalışmada Sermaye Piyasası Kanunu (SPKn) m. 32'ye dayanarak tazminat davası açılması durumunda yatırımcının ispatlaması gereken zararın, tam olarak ne zaman ortaya çıtkı̆̆ belirlenmeye çalışılmıştır. Bu maddeye göre yanlış, yanıltıcı ve eksik bir bilginin yer aldığı kamuyu aydınlatma belgelerinin açılanmasına dayanarak yapılan alım veya satım işleminin ardından düzeltici açılkama yapılması ile yatırımcının ters işlemi yapması sonucu malvarlı̆̆ında meydana gelen zararların tazmin edilmesi söz konusudur. Bu çalışmada ise Türk hukukunda zararın hesaplanmasinda kabul edilen fark teorisine uygun olarak burada tazmin edilmesi gereken zararın, tam olarak yatırımcinın düzeltici açıklamadan sonra ters işlemi yapmasıyla malvarlı̆̆ında meydana gelen azalma olduğu savunulmaktadır.

Anahtar Kelimeler: Kamuyu Aydınlatma, Kamuyu Aydınlatma Belgeleri, Sorumluluk, Zarar, Dura Kararl.

\section{THE TIME LOSS OCCURS IN CIVIL LIABILITY ARISING FROM DISCLOSURE DOCUMENTS IN TURKISH AND U.S.A. LAW}

\section{ABSTRACT}

In this work where the loss as an element of civil law liability arising from disclosure documents is examined, it is considered when the loss occurs exactly to be proved by investor plaintiffs in case of actions for damages based on Article 32 of the Capital Market Law. Pursuant to this article, after the transactions based on the disclosure of documents containing incorrect, misleading and missing information and the following corrective disclosure, an investor can compensate any loss in his property arising from his reverse transaction. In this work, in accordance with the difference theory accepted in Turkish law, the loss to be compensated here is argued to be the decrease in his property when an investor makes the reverse transaction after the corrective disclosure.

Keywords: Disclosure, Disclosure Documents, Liability, Loss, Dura Decision.

\footnotetext{
* Araştırma Görevlisi, Ankara Yıldırım Beyazıt Üniversitesi, Hukuk Fakültesi, Ticaret Hukuku Anabilim Dalı, (nevinmeral@me.com)

${ }^{* *}$ Bu makale, İ.D. Bilkent Üniversitesi Ekonomi ve Sosyal Bilimler Enstitüsü (Hukuk Fakültesi) bünyesinde yazılan doktora tezinden üretilmiştir.
} 
Türk ve ABD Hukukunda Kamuyu Aydınlatma Belgelerinden Doğan Hukuki...

\section{GİRIŞ}

Kurumsal yönetim ilkelerinden biri olarak kamuyu aydınlatma ilkesi, yatırımcıların, yatırım kararı vermeden önce ilgili ihraççı şirketin finansal durumuna, malvarlığına, faaliyetlerine ve ihraç ettiği sermaye piyasası aracına ilişkin bilgileri değerlendirip bilinçlibirkarar vermesini sağlamayı amaçlamaktadır. Bu sayede, birikim sahiplerinin tasarruflarının piyasa aracılığıyla fon ihtiyacındaki şirketlere aktarılması ve yatırımcının da uzun vadede karlı bir yatırım yapması söz konusu olur. Dolayısıyla yatırım kararının sağlıklı bir şekilde oluşması için piyasaya açıklanan ve yatırımcıya sunulan ihraççı ve sermaye piyasası aracına ilişkin bu bilgilerin doğru, açık ve eksiksiz olması gerekmektedir. Özellikle halka açık anonim şirketlerdeki yöneticilerin şirkete, şirketin finansal durumuna ve sermaye piyasası aracına ilişkin daha doğru, ayrıntılı ve ilk elden bilgiye sahip olması ve ortaya bilgi dengesizliğinin çıkması kaçınılmazdır. Bu bilgilerin mevzuatta gösterilen zamanda ve belirlenmiş şekillerde kamuyla paylaşıılması, ihraççı şirkette halihazırdaki yatırımcıların, potansiyel yatırımcılar ile tüm ilgililerin doğru, tam ve açık bilgiye eş zamanlı olarak ulaşması açısından oldukça önemlidir. Aksi halde, özellikle Türkiye'deki şirket profili düşünüldüğünde yöneticiler, denetçiler veya çalışanlar gibi içerdekilerin ellerindeki bilgiyi kazanç sağlamak amacıyla henüz kamuya açılanmadan kullanması mümkündür. Nitekim bilgi dengesizliği sonucunda bazı kişilerin bilgi suiistimali gibi bir yol ile haksız kazanç sağlamaları, piyasada oluşan ve gerçeği yansıtmayan fiyatların ortaya çıkması ve nihayetinde yatırımcının zarar görmesi söz konusu olabilir'.

Yatırımcının sermaye piyasalarına katılımının devamı için öncelikle bilinçli kararlar almasını sağlayarak onu aldatılmaktan korumak; ancak sistemik risk dışındaki başka bir sebeple zarara uğradıysa da zararını tazmin edici mekanizmalar öngörmek gerekmektedir ${ }^{2}$. Illk halde kamuyu aydınlatma ilkesi oldukça önemli ve gerekli olsa da yatırımcı bir kere zarara uğradıktan sonra bu ilkenin tamamlayıcısı olarak kamuyu aydınlatmadan dolayı sorumluluğun öngörülmesi gerekmektedir. SPKn m. 32 uyarınca kamuyu aydınlatma belgelerini imzalayan veya bu belgeler kendi adına imzalanan kişilerle 10. maddede belirtilen kişiler, bu belgelerde yeralan yanlış, yanıltıcı ve eksik bilgilerden kaynaklanan zarardan dolayı sorumludurlar. Çalışmanın da konusunu oluşturduğu üzere SPKn m. 32'de düzenlenen kamuyu

Mustafa Sencer KARA, "Kamuyu Aydınlatma Belgelerinden Doğan Hukuki Sorumluluk," Gazi Üniversitesi Hukuk Fakültesi Dergisi, C. 23, Sa. 2, 2015, s. 133-134; Mustafa İHTIYAR, Sermaye Piyasası Hukukunda Kamuyu Aydınlatma İlkesi, Beta, İstanbul, 2006, s. 182.

2 Ünal TEKİNALP, Sermaye Piyasası Hukukunun Esasları, Ekonomik ve Sosyal Yayınlar, İstanbul, 1982, s. 7; Aysel GÜNDOĞDU, 6362 Sayılı Sermaye Piyasası Kanunu'na Göre Türkiye'de Sermaye Piyasasının Değişen Yüzü, Seçkin, Ankara, 2015, s. 140. 
aydınlatma belgelerinden doğan sorumluluğun kanundan doğan bir sorumluluk olduğu doktrinde baskın görüş olarak kabul edilmektedir ${ }^{3}$. Ancak bu maddede hüküm bulunmayan hallerde, kanımızca uygun düştüğü ölçüde sözleşme veya haksız fiil sorumluluğunun düzenlendiği genel hükümlere başvurulması gerekir.

Bu çalışmada Türk hukukunda kamuyu aydınlatma belgeleriyle açıklanan veya bu belgelerin dayandığı raporlardaki yanlış, yanıltıcı ve eksik bilgiye güvenerek yatırım yapmış olan yatırımcının, bu açıklama sebebiyle meydana gelen zararının tazminini talep etmesi halinde ispatlaması gereken zararının tam olarak ne zaman ortaya çıktığı belirlenmeye çalışılacaktır. Çalışmanın ilk bölümünde kamuyu aydınlatma belgelerinden doğan hukuki sorumluluğun unsurlarına kısaca değinilecek ve bu sorumluluğun bir unsuru olarak zarar kavramı genel hatlarıla açıklanacaktır. İkinci bölümde ise sermaye piyasasında zararın doğduğu ana ilişkin olarak ileri sürülen görüşler, Amerikan Birleşik Devletleri (ABD) hukukunda mevzuat ve dava temelinde yapılan tartışmalardan da yararlanılarak ayrıntılarıyla ele alınacaktır. ABD içtihat hukukunda zararın doğum anına ilişkin özellikle ters işlem yapma görüşünün ortaya atılması ve bu görüşün Türk sermaye piyasas1 hukukuna da uygun olması sebebiyle ters işlem yapma görüşü $\mathrm{ABD}$ içtihat hukukundan yararlanılarak açıklanacaktır. Son bölümde ise ABD hukukunda zararın doğum anına ilişkin benimsenen görüş açıklandıktan sonra Türk borçlar hukukunda ve SPKn m. 32 anlamında tazmin edilmesi gereken zararın doğduğu ana ilişkin olarak benimsenen görüş ayrıntılarıyla ele alınacaktır. Bu bölümde, sermaye piyasasında zararın doğduğu ana ilişkin olarak benimsenen görüş sebebiyle SPKn m. 32/4 hükmünde tazmin edilmesi gereken zarar kavramının, genel hükümlerdeki zarar kavramından daha dar olduğu vurgulanmıştır. Son bölümde ayrıca sermaye piyasası hukukunda benimsenen ters işlem yapma görüşünün zararın ve tazminatın belirlenmesi üzerindeki etkilerine değinilecektir. Sonuç olarak Türk hukukunda baskın görüş olarak benimsenen 'fark görüşü' doğrultusunda ters işlem görüşünde benimsenen zararın, hukuka aykırı açıklama sebebiyle yatırımcının bir sermaye piyasası aracına ilişkin yaptığı işlem fiyatı ile düzeltici açıklamadan sonra ters işlem yapılması ile ödediği fiyat arasındaki fark olduğunu belirtilmektedir.

Adı geçen her iki maddede belirtilen sorumlulukların hukuki niteliği farklı bir çalışma konusu oluşturacağı için ilgili tartışmalar hususunda burada ayrıntıya girilmeyecektir. Çağlar MANAVGAT, Hukuki Bakımdan Halka Açı Anonim Ortaklıkla ve Halka Arz, Banka ve Ticaret Hukuku Araştırma Enstitüsü, Ankara, 2016, s. 260; KARA, s. 166; Buket ÇATAKOĞLU, "Halka Arzda İzahnamenin Hukuki Niteliği ve İzahnameden Doğan Hukuki Sorumluluk," Kastamonu Üniversitesi İiBFD, S. 11, 2016, s. 127; Mehmet Murat İNCEOĞLU, Sermaye Piyasasında Aracı Kurumların Hukuk Sorumluluğu, Seçkin, Ankara, 2004, s. 133; Gökçen TURAN, "Türk Hukukunda İzahnameden Doğan Hukuki Sorumluluğun Esasları,” Gazi Üniversitesi Hukuk Fakültesi Dergisi, C. XX, S. 1, 2016, s. 207. 
Türk ve ABD Hukukunda Kamuyu Aydınlatma Belgelerinden Doğan Hukuki...

\section{KAMUYU AYDINLATMA BELGELERINDEN DOĞAN HUKUKI SORUMLULUK}

\section{Genel Olarak}

Kamuyu aydınlatma belgelerinden doğan sorumluluk ile kastedilen, SPKn m. 32 uyarınca söz konusu belgelerde yer alan yanlış, yanıltıcı ve eksik bilgiler dolayısıyla bu bilgilere güvenerek yatırım yapan yatırımcının uğradığı zararları bu belgelerin altında imzası bulunan kişilerin ve özellikle kanunda gösterilen kişilerin tazmin ile sorumlu tutulmalarıdır. Avrupa Birliği hukukunun aksine Türk hukukunda sermaye piyasası mevzuatında sorumluluk rejimi sorumluluğun süjeleri ve nedensellik bağı gibi konularda oldukça öngörülebilir bir şekilde düzenlenmiştir ${ }^{4}$.

Zarara uğrayan yatırımcının başvurabileceği diğer hukuki yolların başında ihraççının izahname açısından birinci derecede sorumlu olduğu, diğer sayılan aktörlerin de ikinci derecede ve müteselsilen sorumlu olduğu tazminat davaları gelmektedir. Buna ek olarak yatırımcı, kanunda yer alan yönetim kurulu kararlarına karşı iptal davası açma yoluna ya da sorumlu olduğu kısımlar uyarınca bağımsız denetim kuruluşuna tazminat için başvurabilir. Yatırımcı ayrıca Sermaye Piyasası Kurulu'ndan da aydınlatılmayı isteyebileceği için bu hakkın, dolaylı bir hak olarak görülebileceği ileri sürülmüş̧ür5.

\section{Sorumluluğun Niteliği}

Sermaye piyasası hukukuna göre zararın oluştuğu durumlarda hangi sorumluluk hükümlerinin uygulanacağının iyi belirlenmesi gerekmektedir. Zarara sebep olan bilginin yer aldığı belgenin türüne ve hukuki niteliğine göre farklı sorumluluk hükümleri işletilebilecektir. Nitekim yanlış, yanıltıcı ve eksik bilgi izahnamede yer alıyorsa bu durumda izahname sorumluluğunun hukuki niteliğ $i$ gereği öncelikle SPKn m. 10 ve 32 hükümleri ve niteliğine uygun düştüğü ölçüde de genel hükümlerdeki sözleşmesel veya sözleşme öncesi sorumluluk hükümleri uygulanacaktır. Eğer bu tür bir bilgi diğer kamuyu aydınlatma belgelerinden birinde yer alıyorsa yine öncelikle SPKn $\mathrm{m}$. 32'nin uygulanması sonra da uygun düştügü̈ ölçüde genel hükümlere göre sözleşmesel sorumluluk, güven sorumluluğu veya haksız fiil sorumluluğuna başvurulması söz konusu olacaktır.

4 Nusret ÇETIN/ Hatice Ebru TÖREMIŞ/ Zeynep CANTIMUR, 6362 Saylı Sermaye Piyasası Kanunu'nun Sistematik Analizi, Yetkin, Ankara 2014, s. 40-41.

5 Reha TANÖR, Türk Sermaye Piyasası: Taraflar, 1. Cilt, Beta, İstanbul 1999, s. 583-584. 
Türk hukukunda SPKn m. 10/1 ve 32/1 uyarınca izahname ve kamuyu aydınlatma belgelerinde yer alan bilginin yanlış, yanıltıcı veya eksik olması sonucu bir zararın meydana gelmesi halinde sorumluluk doğmaktadır. SPKn m. 32 uyarınca kamuyu aydınlatma belgelerinde hukuka aykırı bilgilerin verilmesinden kaynaklanan sorumluluk, SPKn m. 32/3 hükmü göz önüne alındığında kural olarak kusur sorumluluğudur. Bu doğrultuda bir kimsenin, sözleşme ilişkisi olmaksızın herkese karşı uymak zorunda olduğu bir hukuki görevin veya ödevin ihlali karşısında bir diğer kimseye vermiş olduğu zaran tazmin etme yükümlülüğüne haksız fiil sorumluluğu denmektedir ${ }^{6}$. Türk Borçlar Kanunu (TBK) m. 49 vd. hükümlerinde bu sorumluluk düzenlemektedir, nitekim yatırımcı SPKn hükümlerinin yanı sıra bu genel hükümlere göre de zararının tazmin edilmesini isteyebilir.

ABD hukukunda ise sermaye piyasasında yatırımcının kamuyu aydınlatma dolayısıyla uğradığı zarara ilişkin getirilen sorumluluk hükümlerinin niteliğine bakılacak olursa, sorumluluk hükümleri oldukça karmaşık bir şekilde mevzuata yayılmışıır?. İlk olarak birincil piyasaları düzenleyen 1933 tarihli Menkul Kıymetler Kanunu (Securities Act) §11 hükmünde genel olarak hukuka aykırı olan kayıt belgelerinden ve $\S 12$ hükmünde hukuka aykırı izahnameden doğan sorumluluk düzenlenmiştir8. Bu Kanunun $\$ 11$ hükmüne göre, kayda alma başvurusu sırasında verilen kayıt belgelerinde yani halka arz için çıkarılacak izahnamede veya kayıt için istenen başka bir kamuyu aydınlatma belgesinde hukuka aykırı açıklama yapılması durumunda sorumluluk gündeme gelecektir. Maddede sayılan sorumlular arasında müteselsil sorumluluk bulunmaktadır?.

6 Selahattin Sulhi TEKINAY/ Sermet AKMAN/ Haluk BURCUOĞLU/ Atilla ALTOP, Borçlar Hukuku Genel Hükümler, 6. Bask1, Filiz Kitapevi, İstanbul, 1988, s. 641.

7 Menkul Kıymetler Kanunu §11 hükmüne göre tazmin edilmesini istediği zararı da dahil olmak üzere tüm menkul kıymet hilesi davalarını, yatırımcı asıl olarak Menkul Kıymetler Borsası Kanununda düzenlenen sınıf davası açmak yoluyla ileri sürebilir. Sınıf davası, aynı davalıya karşı birden çok davacının benzer bir haksız fiil dolayısıyla meydana gelen zararlarına ilişkin taleplerini yönelttiği, resmi olarak yalnızca bir veya birkaç temsilcinin davacı olarak göründüğü ve verilen hükmün tüm davacılar için geçerli olduğu bir dava türüdür, TURAN, s. 223. Sınıf davası uygulaması, diğer AngloSakson hukuku ülkelerinde dışarda kalma seçeneği (opt-out procedure) olmadığı için yaygınlaşmamış olmasına rağmen $\mathrm{ABD}$ hukukunda sınıf davasına katılım için davacı yatırımcının sadece söz konusu davaya katılması, hakkında hüküm verilebilmesi için yeterli olmaktadır, Joanna KHOO, "Civil Liability For Misstatements in Offer Documents: Striking the Right Balance," BYU International Law and Management Review, Cilt 6, S. 2, 2010, s. 86-87.

8 \$12 hükmünün zarar ile ilgili bölümü şu şekilde ifade edilmiştir: “... to recover the consideration paid for such security with interest thereon, less the amount of any income received thereon, upon the tender of such security, or for damages if he no longer owns the security.", bkz. 15 U.S. Code §77l, Section 12(a): Civil Liabilities Arising in Connection with Prospectuses and Communications.

9 Sadece bağımsız yönetim kurulu üyelerinin sorumluluğu, başka bir maddeye atıf yoluyla düzenlenmiştir. Bu yöneticilerin sorumluluğu, 1934 tarihli Menkul Kıymetler Borsası Kanunu §21D 
ABD hukukunda bu genel hükmün yanı sıra Menkul Kiymetler Kanunu §12 hükmünde izahname özelinde bir sorumluluk hükmü daha öngörülmüştür ${ }^{10}$. Buna göre aynı kanunun (i) $\S 5$ hükmüne ${ }^{11}$ aykırı olarak bir menkul kıymeti satan veya arz eden kişi ve (ii) esaslı bir bilgiye ilişkin yanlış bir açıklama içeren veya zorunlu olduğu halde hiçbir açılama içermeyen izahname (veya sözlü iletişim araçları) aracılığıyla bir menkul kıymeti satan veya arz eden kişi sorumludur. $\mathrm{Bu}$ madde hükmüne göre kaydedilmemiş bir menkul kıymeti halka arz eden veya satan kimsenin kusursuz sorumluluğu bulunmaktadır.

ABD hukukunda sayılanların dışında öncelikle ikincil piyasaları düzenleyen Menkul Kiymetler Borsası Kanununun (Securities Exchange Act) yanıltıc1 açıklamalardan sorumluluk kenar başlığını taşıyan $\S 18$ hükmüne göre ${ }^{12}$ Menkul Kiymetler Borsası Komisyonuna (SEC) sunulan raporlardan herhangi birinde yanlış veya eksik bir bilginin bulunması dolayısıyla yatırımcının zarara uğraması söz konusuysa ihraççının sorumluluğu doğabilir. Ancak davacı, (i) söz konusu menkul kıymeti alıp satarken SEC'e sunulan hukuka aykırı rapora güvendiğini, (ii) yanlış raporlama sonucunda fiyatların etkilendiğini, (iii) iyi niyetli olduğunu kanıtlamalı ve (iv) mahkemenin talep edeceği sigortayı masrafları karşılayarak yaptırmalıdır. Ancak bu hükümde davacının ispat yükü ağır olduğu için son olarak Menkul Kıymetler Borsas1 Kanunu §10(b) hükmünde kendisine verilen yetkiye dayanarak SEC tarafindan çıkarılan Kural 10b-5 (Rule 10b-5) aracılığıyla mahkemeler sorumluluğa hükmetmeye başlamışlardır ${ }^{14}$. Bu Kural, esaslı bilgilerin yanlış veya eksik açıklanması veya hiç açıklanmamasını; bir menkul kıymetin hileli şekilde alınıp satılmasını yasaklayan; hukuki ve cezai

[78u-4] 'Private Securities Litigation' hükmündeki hile kuralına dayalı olarak açılan ve (f) fikrasında düzenlenen sınıf davalarındaki davalının sorumluluğunun şartlarına göre belirlenecektir.

10 Bkz. 15 U.S. Code, Title 15, Chapter 2A, Subchapter I, §12 [771]: Civil liabilities arising in connection with prospectuses and communications.

1115 U.S. Code, Title 15, Chapter 2A, Subchapter I, $\$ 5$ [77e]: Prohibitions relating to interstate commerce and the mails.

1215 U.S. Code, Title 15, Chapter 2B, §78r: Liability for Misleading Statements.

131934 tarihli Menkul Kıymetler Borsası Kanunu §10(b) hükmünde SEC'e düzenleme yetkisi verilmiştir ve söz konusu Kural, düzenleyici otorite olan SEC'in çıkarmış olduğu bir düzenlemedir. Kural 10b-5 için bkz. Code of Federal Regulations (CFR), Title 17, Chapter II, Part 240, Subpart A, §240.10b-5: Employment of manipulative and deceptive devices: "It shall be unlawful for any person, directly or indirectly, by the use of any means or instrumentality of interstate commerce, or of the mails or of any facility of any national securities exchange ... [t] o make any untrue statement of a material fact or to omit to state a material fact necessary in order to make the statements made, in the light of the circumstances under which they were made, not misleading...".

14 Marvin FECHNER/ Travis TIPTON, "Securities Regulation in Germany and the US," Comparative Corporate Governance and Financial Regulation, Select Seminar Paper 5, 2016, s. 32. 
sorumluluk doğuran ve yatırımcıyı korumayı amaçlayan bir kuraldır. Bu Kurala ilişkin olarak Federal Yüksek Mahkeme içtihatları, common-law dolandırıcılık ve hile görüşlerine dayanmaktadır.

\section{Sorumluluğun Unsurları}

Kamuyu aydınlatma belgelerinden doğan sorumluluğun unsurları sırasıyla ve kısaca, ancak zarar unsuru bütünlük açısından en son incelenecek olursa, söz konusu belgelerdeki bilgilerin gerçeği yansıtmaması durumunda hukuka aykırı eylem meydana gelmiş olmaktadır ${ }^{15}$. Bu belgelerdeki bilgilerin yanlış, yanıltıcı veya eksik olması durumunda hukuka aykırılık meydana gelse de ne tür yanlışlık, yanıltıcılık ve eksikliklerin hukuka aykırılık oluşturacağı (materiality) önem arz etmektedir. Bir bilginin yatırımcıları aldatmasının (yani yanlış, yanıltıcı veya eksik olmasının) yanı sıra o bilginin yatırımcıların sermaye piyasası aracının fiyatına ilişkin değerlendirmesini de etkileyebilecek kadar esash bir bilgi olması gerekmektedir ${ }^{16}$. Esaslı bilgi, makul bir yatırımcının yatırım kararı verirken ancak yatırım yapmadan önce değerlendirebileceği kadar önemli bir bilgidir ${ }^{17}$.

Diğer taraftan SPKn m. 10'da sayllanlar, kamuyu aydınlatma belgelerini imzalayanlar veya bu belgeler kendi adına imzalanan kişilerin SPKn m. 32'ye göre sorumlu olabilmesi için kusurlarının bulunması gerekmektedir ${ }^{18}$. İzahname açısından SPKn m. 10'da kusur derecesi anlamında herhangi bir düzenleme yok iken diğer kamuyu aydınlatma belgeleri açısından SPKn m. 32/3'te kusurun ağır veya hafif olması arasında bir ayrım yapılmıştır. SPKn m. 32/3 uyarınca "[k]атиyu aydınlatma belgelerinde yer alan bilgilerin yanlış, yaniltıcı veya eksik olması konusunda bilgi sahibi olmadı̆̆ın ve bu bilgi eksikliğinin kast veya ă̆ır ihmallerinden kaynaklanmadı̆̆ın ispatlayan kişiler sorumlu olmaz." Kusursuzluğun veya hafif kusurun ispatlanması noktasinda sorumlular aleyhine bir

15 Ayrıca TTK m. 549 uyarınca kamuyu aydınlatma belgelerinde yer alan bilgilerin hileli, sahte olması ya da başka türlü kanuna aykırılıkların bulunması halinde de sorumluluk doğacaktır.

16 Andrew R. SIMMONDS / Kenneth A. SAGAT/ Joshua RONEN, "Dealing With Anomalies, Confusion and Contradiction in Fraud on the Market Securities Class Actions", Kentucky Law Journal, Cilt. 81, 1992-93, s. 125.

17 Bilginin esaslı olup olmadığı belirlenirken ABD hukukunda nesnel ve öznel ölçütler bu şekilde bir arada kullanılmaktadır, Çağlar MANAVGAT, "Bilgiye Dayalı Manipülasyonda Menfaat Elde Etme Şartının Yerindeliği”, BATIDDER, C. XXXIII, S. 2, 2017, s. 37.

18 Menkul Kıymetler Kanunu §11 hükmü uyarnnca, kayıt belgesini imzalayan veya bu belge kendi adına imzalanan kişiler; o anda ihraç̧̧ının ortağı veya yöneticisi olan kişiler; kayıt belgesinde yer alan veya bu belgelere dayanak olan raporları hazırlayı veya onaylayıp rizası ile kayı belgesinde adı yazan uzmanlar; bu menkul kıymete ilişkin aracı kurumlar sorumludur. Maddedeki sorumluların tek tek sayılması sebebiyle bu hükümlerde bir bekçi modeli sorumluluk hükmünün öngörüldüğü belirtilmiştir, FECHNER/ TIPTON, s. 29. 
ispat yükü öngörülmüş; ancak ağır kusur ve kast anlamında aksi ispatlanabilir bir kusur karinesi getirilmiştir. Bu şekilde ayrım yapılması, birincil piyasalarda yanlış, yanıltıcı ve eksik bilgilendirmeden daha fazla zarar görecek yatırımcı ve arz edenin kazançlı olması halinde sosyal zararın artması; ikincil piyasalarda ise bu durumun nispeten az görülmesi açısından makul karşılanabilir ${ }^{19}$. Ancak zararının doğması noktasında herhangi bir fark oluşturmadığı düşünüldügüünde, yatırımcının etkin bir şekilde korunması amacına ters düştüğü için kusurun derecesi açısından bir ayrıma gidilmesi doktrinde eleştirilmiştir ${ }^{20}$. Ayrıca SPKn m. 32/3 uyarınca kamuyu aydınlatma belgelerindeki bilgilerin yanlış, yanıltıcı ve eksik olduğu durumlarda, bu hususta "bilgi sahibi olmadığını ve bu bilgi eksikliğinin kast veya ă̆ır ihmalinden kaynaklanmadığını" ispatlayanlar sorumlu olmayacaktır. ABD hukukunda ise, 1933 tarihli Menkul Kiymetler Kanunu $\$ 12$ hükmüne göre izahnamede veya sözlü iletişim aracındaki açıklamadaki yanlışlığı veya eksikliği makul bir özeni gösterseydi dahi bilemeyeceğini veya nedensellik bağının kesildiğini ispatlayan kişi, sorumlu tutulmaz.

Yatırımcının, kamuyu aydınlatma belgelerindeki esaslı olan yanlış, yanıltıcı veya eksik bilgilerin hukuka aykırı bir eylem sonucu kamuya açıklanması dolayısıyla maddi zarara uğramış olması yani bu belgelerde bulunan bilgilerin niteliğinin zarara sebebiyet vermesi arasında nedensellik bağı bulunmalıdır. Özellikle piyasada, sermaye piyasası aracının değerini etkileyen birçok faktör düşünüldüğünde yatırımcının zararının aslında kamuyu aydınlatma belgelerindeki yanlış, yanıltıcı veya eksik bilgilerden kaynaklandığını ispatlaması gerekli ve önemlidir ${ }^{21}$. Nedensellik bağının yatırımcı tarafından ispatının zorluğu düşünüldüğ̈ünde SPKn m. 32/4'te sınırları belirli bir adi nedensellik bağı karinesi getirilmiştir ${ }^{22}$. İlk halka arzdan veya borsada satın alınan veya satılan sermaye piyasası araçlarının, gerçeğe uygun bilginin ortaya çıkmasından hemen sonra satın alınması veya satılması halinde zarar ile kamuyu aydınlatma belgesi arasında nedensellik bağı kurulmuş sayılır; ancak bunun için bir zaman sınırlaması

19 MANAVGAT, (2016), s. 233.

20 ÇATAKOĞLU, s. 129-130; MANAVGAT, (2016), s. 233.

21 Ancak buradaki nedensellik bağını ikiye ayırarak incelemekte fayda vardır: Öncelikle yanlış, yanıltıcı veya eksik açıklanan bilgilerin piyasadaki fiyatları etkilediğinin (işlem nedenselliği: transaction causation; common-law kaynaklı hile ve hukuka aykırı açıklama davalarındaki muadili ise reliance olarak adlandırılır.) ve sonra da duruma göre bu fiyatlardaki düşüşün veya yükselişin de yatırımcının zararına sebep olduğunun (zarar nedenselliği: loss causation) ispatlanması gerekir.

22 Bu maddeye göre tazmin edilebilecek olan zararın tanımının da bu fikradan anlaşılabileceğine ilişkin olarak bkz. Mustafa KESKIN, Halka Açık Anonim Ortaklıkların Kamuyu Aydınlatma Yükümlülüğ̈̈, Oniki Levha, İstanbul, 2018, s. 114. 
getirilmiştir: (i) yanlış, yanıltıcı ve eksik bilgi içeren izahnameler geçerlilik süresi boyunca (ii) diğer kamuyu aydınlatma belgeleri kamuya açıklandığı tarihten hemen sonra, bu alım veya satımın gerçekleşmesi gerekir. Yani izahnamenin geçerli olduğu 12 ay boyunca (SPKn m. 9), bu belgedeki yanlış, yanıltıcı veya eksik bilgilere güvenilerek yatırımcı tarafindan yapılan işlemler için illiyet bağ karinesi söz konusudur. Diğer kamuyu aydınlatma belgeleri açısından ise zararın, gerçeğe uygun bilginin ortaya çıkmasından hemen sonra sermaye piyasası aracının alım-satımının yapılmasıyla doğması gerekmektedir.

SPKn m. 32 uyarınca kamuyu aydınlatma belgelerinden doğan sorumlulukta zarar unsuruna, ayrıntılı olarak daha sonra değinileceği için bu kısımda, söz konusu madde anlamında zararın tanımı yapılarak genel çerçevesi çizilecektir. Zararın bir tanımını kanun koyucu tarafından yapılmadığı için doktrin ve yarg1, zararı geniş anlamda ve dar anlamda zarar olarak ikiye ayırmak suretiyle tanımlamaktadır. Zarar, malvarlığının zarar verici eylemden sonra zarar görenin rızası dışında oluşan son durumu ile bu eylem meydana gelmeseydi malvarlığının o durumu arasındaki farktır. Malvarlığının bu iki durumu arasındaki fark, zarar görenin menfaatidir; nitekim Yargıtay bu görüşü içtihatlarında benimsemiştir ${ }^{23}$. Buna göre dar anlamda zarar, malvarlığında zarar görenin rızası dışında meydana gelen azalma yani maddi zarardır. Geniş anlamda zarar, bir kimsenin maddi veya manevi varlığında iradesi dışında meydana gelen azalma olarak tanımlanmakta ve maddi ve manevi zararı kapsamaktadır ${ }^{24}$. Sorumluluk hukukunda tazminat

23 Zararın tanımında fark teorisinin açıklaması için bkz. Fikret EREN, Borçlar Hukuku Genel Hükümler, 21. Baskı, Yetkin, Ankara, 2017, s. 545 vd.; Tamer İNAL, Borca Aykırılı, Dönme ve Fesih, 6. Baskı, Seçkin, Ankara, 2017, s. 478-479; Yargıtay uygulaması için örnek olarak bkz. Yargitay 4. H. D. 27.02 .1975 tarihli ve 13954/274 sayll Kararı.

24 Zarar, maddi-manevi zarar, malvarlı̆̆ı-şahıs varlığı zararı, fili zarar-kazanç kaybı veya normatif zarar şeklinde çok çeşitli ayrımlara tabi tutulabilmektedir ve bunlardan en önemlisi maddi ve manevi zarar ayrımıdır. Diğer taraftan hukuka aykırı bir eylemin zarar verdiği varlığın türüne göre malvarlığı ve şahıs varlı̆ı̆ zararları şeklinde yapılan bir ayrım da mevcuttur. Zarar gören kişinin malvarlığına yönelik zararlar, malvarlığı zararı iken kişinin şahıs varlığına yönelik zararlar şahıs varlığı zararını oluşturmaktadır. Yapılan diğer bir ayrıma göre, zarar görenin malvarlı̆̆ında iradesi dışında meydana gelen ve zarar verici olay meydana gelmeseydi kişinin malvarlığının durumu değişmeyecek idiyse burada gerçekleşen fiili azalma, fiili zarardır. Diğer bir ifadeyle zarar görenin rızası dışında malvarlığının aktifindeki fiili bir azalma veya pasifindeki bir artış, fili zarardır.

Tüm bu ayrımların yanı sıra Alman ve Avusturya doktrininde çokça tartışlan normatif zarar olarak adlandırılan başka bir zarar türü de mevcuttur. Buna göre şeyin, hasar görmesi sebebiyle ticari anlamda değerinde bir azalma meydana gelmesi veya şeyi kullanmaktan yoksun kalınması sonucunda kişinin zarara uğradığı kabul edilmektedir. Normatif zarar, içerisinde maddi ve manevi zararın unsurlarını barındırmakta ve malvarlığında fiili bir azalmaya yol açmasa da kişinin dinlenme zamanının harcanması gibi zararları dahi kapsamaktadır. Burada ticarileşmiş bazı değerlerin malvarlığına dahil edilmesi sonucu bu değerlerin azalması veya kaybolması sonucunda, şeyin kullanım değeri dolayısıyla bir kimsenin malvarlığında meydana gelen herhangi bir azalma olmasa dahi maddi zarar oluşacağı ve 
yükümlülüğü doğuran zarar türü ile daha çok, dar anlamda zarar yani maddi zarar kastedilmektedir. Maddi zarar, malvarlığı veya şahıs varlığı değerlerinden herhangi birine yönelik olan hukuka aykırı bir eylem sonucunda bir kimsenin malvarlığında meydana gelen eksilmedir ${ }^{25},{ }^{26}$.

Zararın olmadığı yerde hukuki sorumluluk meydana gelmez; dolayısıyla zarar vermeye teşebbüs, zarar görme ihtimali veya farazi zarar gibi durumlarda gerçek zarar meydana gelmediği için sorumluluk da doğmayacaktır ${ }^{27}$. Zararın gerçekleşmiş olması veya gerçekleşmesinin kesin olması halinde zarar doğduğu kabul edilir ve zararı tazmin yükümlülüğü doğar. Dolayısıyla zarar gören TBK m. 50/1 uyarınca hukuka aykırı bir eylem ile zarara uğradığını ve zarar verenin kusurunu ispatlamak yükümlülüğü altındadır. Burada sözleşmesel sorumluluktan farklı olarak zarar gören, zarar verenin kusurunu ve zararı her türlü delille ispatlayabilir ${ }^{28}$.

Sorumluluk hukukunda hukuka aykırı her fiil zarara sebep olmamakta ve her zarar da tazminatı gerektirmemektedir; dolayısıyla ihlal edilen hukuk kuralı zarar

tazminat istenebileceği öngörülmektedir, bkz. Kemal OĞUZMAN/ Turgut M. ÖZ, Borçlar Hukuku Genel Hükümler, Cilt I, 14. Bask1, Vedat, İstanbul, 2016, s. 392-393, no. 1293-1294; TEKİNAY, s. 737. Özellikle Türk hukukunda baskın olarak kabul edilen ve zararın hesaplanmasında kullanılan fark teorisinin geleneksel zarar anlayışına uygun olmasına rağmen artık günümüze uygun olmadığı gerekçesiyle ortaya çıkmıştır (Ahmet M. KILIÇOĞLU, Borçlar Hukuku Genel Hükümler, 21. Bası, Turhan, Ankara, 2017, s. 395-396. Alman hukukunda BGB §651f hükmü ile tatilin sonuçsuz kalması veya zamanının önemli ölçüde harcanması nedeniyle tatil imkanından yoksun kalan kişinin zarara uğradığı ve bunun tazminini isteyebileceği kabul edilmiştir. Benzer şekilde İsviçre hukukunda da ev işlerini yürüten eşin vücut bütünlüğünün ihlal edilmesi halinde işgücü kaybı nedeniyle uğradığı zararlar bu kapsamda kabul edilmiştir, KILIÇOĞLU, s. 396). Ancak Türk hukukunda gerçek ve fiili bir zarar olmadan tazminat isteme imkanı doğduğu için normatif zarar teorisi eleştirilmektedir (OĞUZMAN/ ÖZ, Cilt I, s. 393, no. 1294; Kemal OĞUZMAN/ Turgut M. ÖZ, Borçlar Hukuku Genel Hükümler, Cilt II, 12. Bask1, Vedat, İstanbul, 2016, s. 42-43, no. 125; TEKINAY, s. 740 ve 742-743). Türk hukukunda bu zarar türü aynca bulunmamakta, şartları varsa tabii zarar (gerçek zarar) olarak nitelendirilmekte ve manevi zarar yönü ağır basmakla birlikte maddi ve manevi zarar içerisinde değerlendirilmektedir (Nitekim hasar görmüş arabanın bağımsız sürüm değerindeki azalmalar sonucunda alacaklının oluşan bu maddi zararını tazmin edeceği Türk hukukunda halihazırda kabul edilmektedir, TEKINAY, s. 739; KILIÇOĞLU, s. 396. Bu tür normatif zararların MK m. 24, TBK m. 49 ve 58'e göre tazmin edileceği doktrinde ileri sürülmüştür, KILIÇOĞLU, s. 397). Normatif zarar ve ayrıntıları için bkz. EREN, s. 545 vd.; TEKINAY, s. 736-751.

25 KILIÇOĞLU, s. 389.

26 Maddi zararda var olan eksilme, malvarlığında kendini göstereceği için kolayca ispatı mümkündür, KILIÇOĞLU, s. 389-390. Bu durumda uğranılan manevi zararın bir şekilde dışa yansıyan değerlerle ifade edilerek kanıtlanması gerekmektedir, KILIÇOĞLU, s. 390.

27 EREN, s. 542; Mehmet AYAN, Borçlar Hukuku (Genel Hükümler), 10. Baskı, Mimoza, Ankara, 2015, s. 520; TEKINAY, s. 732-733.

28 Burada haksız fiillere HMK m. 200'deki belgeyle ispat kuralı uygulanmaz. Ayrıca HMK m. 187/2 uyarınca davacının, bilinen olayları ispatlamasına gerek yoktur. 
görenin mutlak bir hakkını ihlal etmiyorsa veya menfaatini korumak amacıyla getirilmemişse, zarar görenin, tazmini gerektiren bir zarara uğradığı söylenemez ${ }^{29}$. Burada da ilgililerin sorumlu tutulabilmesi için yatırımcının, kamuyu aydınlatma belgelerindeki bilginin yanlış, yanıltıcı veya eksik olması nedeniyle rızası dışında bir zararının doğması gerekmektedir. Sermaye piyasasında mevzuata uygun bir şekilde faaliyet gösteren yatırımcının, özellikle fiyat dalgalanmaları sebebiyle oluşan olağan risk dışında kendinden kaynaklanmayan risklerle karşılaşması halinde ortaya çıkan zararının karşılanması gerekmektedir ${ }^{30}$. Açılacak tazminat davasının konusu, kamuyu aydınlatma belgelerinde yanlış, yanıltıcı veya eksik bilgi bulunmasından dolayı sorumlu bulunan kişilerin, bu hukuka aykırılıktan dolayı zarar görmüş olan yatırımcının zararını tazmini olacaktır. Hukuki niteliği itibariyle bir eda davası veya alacak davası olan tazminat davası ile davac1 yatırımc1, zarar verici eylemle uğradığı zararının nakden giderilmesini talep eder. Buradaki zarar kavramının ortaya çıtığı an ve buna bağlı olarak zararın kapsamının belirlenmesi, tazminat sorumluluğunun doğması açısından gereklidir.

\section{SERMAYE PIYASASINDA ZARARIN DOĞDUĞU ANA ILIŞKIN GÖRÜŞLER}

\section{Genel Olarak}

Kamuyu aydınlatma belgelerinde hukuka aykırı bir açıklama yapılmasından dolayı ortaya çıkan zararın tanımı ve dolayısıyla kapsamının belirlenmesine ilişkin bazı görüşler ileri sürülmüştür. Birinci görüsse göre, yatırımcının yanlış, yanıltıcı veya eksik bilgilerin kamuya açıklanması ile salt yapay fiyattan işlem yapmış olması, zararın ortaya çıkması için yeterlidir. İkinci görüş uyarınca yapay fiyattan alım veya satım yapılmış olmasının yanı sıra gerçek bilginin kamuya sunulmasının fiyatlar üzerinde etkili olmasıyla gerçek fiyatın belirlenmesi sonucunda ortaya çıkan yapay fiyat ve gerçek fiyat arasındaki fark, yatırımcının zararını oluşturmaktadır. Ancak sonrasında ortaya çıkan üçüncü bir görüşe göre yatırımcının düzeltici açıklamadan sonra ters işlemi yapmasıyla zararın meydana geleceği savunulmaktadır.

\section{Yapay Fiyattan İşlem Yapma Görüşü}

ABD'de ekonomi biliminde ortaya atılan etkin piyasa teorisine (Efficient Market Theory) ${ }^{31}$ dayanarak hukuk alanında Piyasada Dolandırıcılık (Fraud on-

29 TEKINAY, s. 734-735; OĞUZMAN/ÖZ, Cilt I, s. 15; KESKINN, s. 113-114

30 Serdar KARABABA, Hisse Senedi Yatırımcısının Korunması, Seçkin, Ankara 2001, s. 41.

31 Etkin piyasa teorisine göre fiyatlar, bir menkul kıymetin gerçek değerini yansıtma anlamında ölçü 
the-Market) teorisi adıyla yenibirteori kendini göstermiştir. Piyasada dolandırıcılık teorisine göre fiyatların açıklanan tüm bilgileri yansıttığı ve piyasanın bir bütün olarak etkin bir şekilde işlediği ve bu fiyatların, menkul kıymetlerin gerçek değerini yansıttığı kabul edilir. Dolayısıyla bu fiyatlara güvenerek yatırım kararı veren yatırımcıların, belirli açıklamalardan sonra zarara uğraması, piyasanın etkin olmadığını gösterir. Buna sebep olan kişilerin ise yaptıkları açıklamadan dolayı sorumlu olması ve yatırımcının zararını tazmin etmesi beklenir. Piyasada dolandırıcılık teorisinde yatırımcının, piyasanın etkin olmaması sebebiyle bir menkul kıymete, olması gerekenden daha yüksek bir bedel ödemiş olması doğrudan onun zarara uğradığının göstergesidir ${ }^{32}$.

Yapay fiyattan işlem yapılmasını, zararın oluşması için yeterli gören bu görüşe göre, kamunun yanlış, yanıltıcı veya eksik bilgilendirilmesi veya hiç bilgilendirilmemesi sonucunda fiyatlarda yapay bir etki görülecektir. Kamudan olumsuz bir bilginin saklanması halinde, yatırımcının yapay yüksek fiyat üzerinden bir menkul kıymeti alması sonucunda malvarlığında, o aracı gerçek fiyatından alsaydı malvarlığında oluşacak azalmadan daha fazla oranda azalma meydana gelecektir. Örneğin bir menkul kıymetin piyasadaki fiyatının üç birim olduğu durumda, şirketin aslında borca batık olduğuna yönelik bilginin kamuya açıklanması halinde bu aracın fiyatı bir birime düşecekse, içsel bilginin kamuya açıklanmaması ile yatırımcının bu aracı üç birimden satın alması anında yatırımcı zarara uğramaktadır. Yatırımcının malvarlığında bu şartlarda üç birimlik bir azalma meydana gelmiştir; ancak içsel bilgi kamuya açıklansaydı, bir birimlik azalma meydana gelecekti. Dolayısıyla, bu görüşe göre yatırımcı daha işlemi yaptığı anda menkul kıymetin fiyatının hileli şekilde oluşması sonucu zarara uğramıştır.

Bu görüşe göre yatırımcının uğradığı zararı belirlemek için genel hükümlerdeki kuralların uygulanması uygun değildir ${ }^{33}$. Nitekim genel hükümlerdeki zarar kavramına göre, yapay fiyat ile gerçeğe uygun bilginin ortaya çıkmasından sonra fiyatların sabitlendiği gerçek fiyat arasındaki fark, zararı oluşturmaktadır. Daha çok, satarken düşük fiyata satma veya hala elinde bulunan menkul kıymetin değerinin

olarak kabul edildiğinde piyasalar güçlü, yarı güçlü ve zayıf olarak üçe ayrılmaktadır. Bunlardan güçlü piyasa modelinde, bir şirket tarafindan açıklanmış ve açıklanmamış tüm bilgilerin fiyatlara yansıdığı kabul edilirken, yarı güçlü piyasa modeli uyarınca piyasa fiyatlarının sadece açıklanan tüm bilgileri yansıttığı varsayılmaktadır. Ancak günümüz piyasalarının yarı güçlü piyasa modeline benzediği genel olarak kabul edilmektedir.

32 Merritt FOX, "Demystifying Causation in Fraud-on-the Market Actions," The Business Lawyer, Cilt 60, 2005, s. 523-524. Bu yönde örnek niteliğindeki temyiz mahkemesi kararı için bkz. In re Control Data Corp. Sec. Lit., 993 F.2d 616 (8th Cir. 1991).

33 FOX, s. 514. 
düşmesi suretiyle zarara uğrama şeklinde gerçekleşen geleneksel zarar kavramının, ABD hukukundaki Kural 10b-5'te kabul edilen menkul kıymet hilesi davalarında da yanlış bir şekilde uygulandığı düşünülmektedir ${ }^{34}$. Nitekim geleneksel anlamda zarar, yüz yüze veya halka arz gibi doğrudan yapılan sözleşmelerde meydana gelebilecek iken bu görüşte ikincil piyasada yapılan işlemler için meydana gelen zararın farklı bir niteliği olduğu kabul edilir ${ }^{35}$. Burada zarar, yatırımcının, aslında kamuya yapılan açıklamayı duymamış olsa bile piyasadaki fiyatların gerçeği yansitmaması dolayısıyla aldatılması ve bir menkul kıymete ederinden daha fazla ödemiş olmasından kaynaklanır ${ }^{36}$.

$\mathrm{Bu}$ görüşün en önemli savunucularından Fox'a göre sorumluluğun doğabilmesi için piyasanın tepki verip gerçeğe uygun bilgiyi algılaması ve fiyatlara yansıtması ile bu süreçte fiyatları etkileyen başka herhangi bir gelişmenin yaşanmaması gerekir ${ }^{37}$. Piyasanın ne zaman doğru bilgiyi algılayıp tepki vereceğinin de bu durumda belirlenmesi önemli hale gelmektedir, çünkü düzeltici açıklamadan sonra piyasa doğru bilgiye tepki vermeden önce elindeki menkul kıymeti satan yatırımcının bir de hukuka aykııı açıklamadan dolayı tazmin edilmesi hakkaniyete aykırı olacaktır ${ }^{38}$. Ancak günümüz piyasa koşullarında sadece bilginin fiyatı etkilediği söylenemez. Fiyatı etkileyen başka etkenler özellikle kişisel etkenler düşünüldüğünde sermaye piyasasındaki zarar kavramının genel hükümlerdeki zarar kavramından oldukça farklı olduğu söylenebilir ${ }^{39}$. Bunların da ötesinde kamuyu aydınlatmanın yanlış, yanıltıcı veya eksik yapıldı̆̆ 1 durumlarda, gerçek bilgi ortaya çıkmadan istenebilecek tazminatlar açısından zararın belirlenebilmesi için menkul kıymetin gerçek fiyatının varsayımsal olarak tespit edilmesi gerekir.

Bu noktada yapay fiyatlardan alım veya satım yapan yatırımcının, gerçeğe uygun bilgi ortaya çıkmadan önce yine yapay fiyatlar üzerinden satım veya

34 FOX, s. 512; CHAMBLEE BURCH, s. 351. Federal Yüksek Mahkeme şimdiye dek Kural 10b-5'e dayanan tazminat davalarında işlem ve zarar nedenselliğinin aranmasına ilişkin olarak hiçbir yorum yapmamış olsa da bu yanlış uygulama aslında daha alt derecelerdeki mahkemeler tarafindan oluşturulmuştur. $\mathrm{Bu}$ hükümde düzenlenen dava, gerek geleneksel güvene dayanarak gerekse de piyasada dolandırıcilığa dayanarak açılabilir; ancak ilk halde açılacak davada geleneksel zarar kavramı ile diğerindeki zarar kavramı farklı kavramlardır, FOX, s. 515.

35 FOX, s. 513-514.

36 FOX, s. 517.

37 FOX, s. 524.

38 FOX, s. 523.

39 Robbins v. Koger Properties, Inc. 116 F.3d 1441 (11th Cir. 1997), s. 1447; MANAVGAT, (2016), s. 246. 
alım yapması durumunda zararının yine de ilk işlem yapıldığında oluştuğu ileri sürülebilir. Yatırımcının aslında bir menkul kıymeti aldığ fiyata satması ya da sattığı fiyattan alım yapması halinde malvarlığında oluşacak herhangi bir azalma olmayacağı için gerçekten zarara uğradığı ve dolayısıyla sorumluluğun doğduğu söyleneme ${ }^{40}$. Bu yüzden, yatırımcının yapay fiyat üzerinden ilk kez işlem yaptığında zararının oluştuğunu kabul edenler bile bu durumda istisnai olarak yatırımcının tazminata hak kazanamayacağını belirtmektedirler ${ }^{41}$. Ayrıca kamuya açıklamanın hiç yapılmadığı durumlarda piyasa fiyatının değişmeksizin sabit kalması, ortaya bir yapay fiyat çıkmaması sonucu zararın varsayımsal fiyat üzerinden hesaplanması oldukça zordur. Söz konusu varsayımsal fiyatın, özellikle de kamunun hiç bilgilendirilmediği hallerde, tam olarak ya da gerçeğe yakın bir şekilde tespit edilebilmesi mümkün değildir ${ }^{22}$. Diğer taraftan hukuka aykırı birden fazla bilgilendirmenin yapılması sonucu yapay fiyatların oluşmasında; ya da gerçeğe uygun bilginin ortaya çıkmasıyla fiyatların değişmesinin sonucunda yatırımcının hangi bilgilendirme dolayısıyla zarara uğradığını kanıtlamasına gerek yoktur. Yatırımcının ilk durumda kanıtlaması gereken tek şey, yapay fiyattan işlem yaptığına dair maddi vakıadır; ikinci durumda ise alım veya satım yaptığ yapay fiyat ile piyasada fiyatların gerçek bilginin açıklanmasından sonra değiştiği olgusudur. Bu durumda her iki görüşe göre de temel alınan zarar kavramının mutlak olarak fiyattaki etkilenmeyle tanımlanmasının, sorumluluk davalarının sınırını ciddi ölçüde genişlettiği görülmektedir ${ }^{43}$.

\section{Fark Görüşü}

Etkin piyasa teorisine dayanan piyasada dolandırıcılık teorisine göre nedensellik bağının varsayımsal olarak yapay fiyattan menkul kıymet alımıyla birlikte kurulduğu ve dolayısıyla zararın meydana geldiği kabul edilmektedir ${ }^{44}$. Ancak fark görüşünü destekleyenlere göre, yatırımcının bir menkul kıymeti için piyasada hukuka aykıı açıklama sonrasında yapay fiyattan alım veya satım yapması, sadece ileride zararın doğmasını tetikleyici niteliktedir; ancak tek başına bu hususun, zarar doğurucu bir niteliği bulunmamaktadır ${ }^{45}$. Sorumluluğun ve ödenecek tazminat kapsamının zarara göre belirlendiği düşünüldüğünde zarar

\footnotetext{
40 MANAVGAT, (2016), s. 250.

41 FOX, s. 522.

42 MANAVGAT, (2016), s. 250 ve 253.

43 MANAVGAT, (2016), s. 253.

44 Ayrnntılı bilgi için bkz. Supreme Court of United States, Katyle v. Penn Nat'l Gaming, Inc. 637 F.3d 462 (4th Cir. 2011), s. 472; ayrica bkz. Taylor v. Keycorp, 680 F.3d 609 (6th Cir. 2012), s. 613.

45 MANAVGAT, (2016), s. 251.
} 
kavramının içeriğinin tam olarak belirlenmesi önem arz etmektedir; nitekim zararın varsayımsal fiyat üzerinden belirlenmesini eleştiren Coffee öncülüğ̈̈nde ikinci bir görüş ortaya çıkmıştır. Ekonomi biliminin hukuk biliminden çok farklı bir anlayışa sahip olması sebebiyle etkin piyasa teorisinin hukuki platformda uygulama alanı bulması pratikte çeşitli sorunlara sebep olur ${ }^{46}$. Zararın varsayımlarla mahkemelerde kabul edilmesi, piyasa açısından söz konusu bilginin esaslı bulunduğu anlamına gelmeyeceği gibi, mahkemelerin tarihi güçlerinin ötesine geçmesine sebep olur ${ }^{47}$. İlk görüş̧e zararın farazi ve belirsiz bir zarar olarak tanımlanması eleştirilmiş ve yargının, açılamadaki hukuka aykırılığın esaslı olduğuna karar verebilecek yetkinlikte olduğu kabul edilse bile doğru bilginin açıklanmasının ardından piyasanın nasıl tepki vereceğini güvenilir şekilde ölçemeyeceği doktrinde vurgulanmıştır ${ }^{48}$. Fiyatların varsayımsal olarak mahkemeler tarafindan değil piyasada belirlenmesi gerektiğine inanan bu görüş, piyasa odaklı bir zarar tespiti yapmaktadır ${ }^{49}$.

ABD haksız fiil hukukunda da bir şirketin finansal durumu hakkında yanıltıcı açıklamada bulunan bir kişinin, bu açıklamaya güvenip alım işlemi yapmış ancak doğru bilginin piyasadaki düzeltici açıklama ile öğrenilmesi sonrasında fiyatlar düştügü için zarara uğramış kişiye karşı sorumlu olduğu belirtilmiştir ${ }^{50}$. Yatırımcının, bu durumda hukuka aykırı bir açıklama dolayısıyla açacağı tazminat davasında, doğru bilgi açıklansaydı işlem yapmayacağını ve dahası, açıklamaya güvenip işlem yaptığı için zarara uğradığını kanıtlaması gerekmektedir ${ }^{51}$. Esaslı olan bir olumsuz bilginin ve olumlu bilginin benzer zamanlarda kamuya açıklanmaması söz konusu olduğunda piyasa fiyatı aslında payın gerçek değerini de yansıtıyor olabileceğinden, yatırımcının bundan zarara uğradığı söylenemez ${ }^{52}$. Diğer taraftan ikincil piyasadan pay satın alan yatırımcının, herhangi bir hukuka aykırılıkla bağlaştırılamayacak piyasa balonu sebebiyle yüksek bir bedel ödemesi sonucu

\footnotetext{
46 COFFEE, s. 541.

47 COFFEE, s. 534.

48 COFFEE, s. 538.

49 COFFEE, s. 534; MANAVGAT, (2016), s. 251.

50 The Restatement (Second) of Torts, §548A, Comment b, s. 107. Dolayısıyla düzeltici açıklamanın aslında ne zaman yapıldığının belirlenmesi de gerekmektedir. Dura kararından sonra, düzeltici açıklamaların piyasada aslında her gün yapıldığı belirtilmektedir, NIELSEN/PROWSE, s. 21. Bazen yatııımcı, hukuka aykırı açıllama yapıldığı ve hatta düzeltici açıklamanın yapıldığını bile anlayamamaktadır. Düzeltici açıklamadan sonra piyasanın tepki verdiği an, fiyatların normal seyrinden farklı şekilde ve istatistiksel olarak da ciddi şekilde düşmesi ('noise') sonucu anlaşılabilir, NIELSEN/ PROWSE, s. 21-22.

51 MANAVGAT, (2016), s. 252.

52 COFFEE, s. 538.
} 
zarara uğradığı söylenemez ${ }^{53}$. Ancak bazen esaslı bilginin piyasaya açıklanması da hiç açıklanmaması ile aynı sonuçları doğurabilir: hukuka aykırı bilgi sonucunda oluşan yapay fiyatların ardından doğru bilginin açılanması üzerine piyasa fiyatlarının düşmesi ile söz konusu bilginin piyasaya doğrudan açıklanması sonucu fiyatların düşmesi aynı şekilde olabilir ${ }^{4}$.

$\mathrm{Bu}$ görüş, gerçek bilginin kamuya açılanmasından önce piyasada yapay fiyattan bir menkul kıymetin alım veya satımının yapılmasını müteakip gerçek bilginin ortaya çıkması ve fiyatların etkilenmesi sonucu oluşan gerçek fiyat ile alım veya satım işleminin yapıldığı yapay fiyat arasındaki farkı zarar olarak nitelemektedir. Dolayısıyla zarardan söz edebilmek için, yapay fiyattan işlem yapılmasının yanı sıra, gerçek bilginin düzeltici bir açıklama ile kamuya sunulması ve piyasadaki fiyatların bu bilgiden etkilenmesi sonucu değişerek gerçek fiyatta sabitlenmesi gerekmektedir ${ }^{55}$. Burada yatırımcının zararının doğduğu an, gerçek bilginin düzeltici açıklamadan sonra piyasaya etki etmesi sonucu fiyatların değişime uğradığı ve gerçek fiyatın oluştuğu andır. Zararın kapsamını yani ödenecek tazminatın kapsamını ise işlem yapılan fiyatla gerçek bilginin piyasayı etkilemesi sonucu değişen son fiyat arasındaki fark belirlemektedir.

\section{Ters İșlem Yapma Görüșü}

Fark teorisine göre bir yatırımcının menkul kıymete ilişkin işlem yaptı̆ğ fiyat ile düzeltici açıklamadan sonra piyasanın bu düzeltmeye tepki vermesi sonucunda o aracın fiyatının değişiklik göstermesi ve ilk işlemin yapıldığı yapay fiyat ile sonradan gerçekleşen gerçek fiyatın arasında bir farkın olması gerekmektedir. İște bu iki fiyat arasındaki fark, fark teorisine göre yatırımcının zararını oluşturmaktadır. Ancak ABD Federal Yüksek Mahkemesi Dura kararında ${ }^{56}$ yatırımcının düzeltici açıklamadan sonra ters işlemi yapmamış olması halinde gerçek bir zararının oluşmayacağını, bir zarar doğsa bile bunu ihtimaller sonucu ifade etmenin uygun olmadığını vurgulamıştır.

53 COFFEE, s. 538-539.

54 Daniel R. FISCHEL, "Efficient Capital Markets, the Crash and the Fraud on the Market Theory," Cornell Law Review, Cilt 74. 1989, s. 910, dn. 6.

55 Nitekim bu görüş, ABD hukukunda 1933 tarihli Kanunu §12(b) hükmünde de birincil piyasalar için açıkça kabul edilmiştir. Semerenko v. Cendant Corp. 223 F.3d 165 (3rd Cir. 2000), s. 185. Ayrıca bkz. MANAVGAT, (2016), s. 247.

56 Supreme Court of United States, Dura Pharmaceuticals, Inc. v. Broudo et all. (No. 03-932) 544 U.S. $336(2005)$. 
2005 tarihli Dura davasında Bölge Temyiz Mahkemesinin kararın1 ${ }^{57}$ bozan Federal Yüksek Mahkeme, sadece yanlış, yanıltıcı veya eksik kamuyu aydınlatma sonucu yükselen yapay fiyattan alım yapmanın ve bu hususun ispat edilmesinin, zararın doğması için yeterli olmadığını belirtmiş̧iir ${ }^{58}$. Dolayısıyla Mahkeme, birinci görüşün tanımladığı zarar kavramını reddetmiş ve salt işlem yapmakla zararın doğmayacağını belirtmiştir. Yapay fiyattan alım yaptıktan sonra, düzeltici açılama yapılmadan ve doğru bilgi ortaya çıkmadan payların yine yüksek bir fiyattan satılabilmesi ihtimali ${ }^{59}$ olduğu için zarar, malvarlığında gerçek bir azalma ile ortaya çıkmalıdır ${ }^{60}$. Nitekim geleneksel hile davalarında davacının, gerçek bir ekonomik zararının olduğunu ispatlaması gerekmektedir ve menkul kıymet hilesi davalarının temelinde bu common-law hilesi olduğu için menkul kıymet hilesindeki zarar anlayışı, buradaki zarar anlayışına (actual damage) dayanmalıdır ${ }^{61}$. Bu geleneksel yorum tarzı, piyasada dolandırıcılık teorisinin kabul edildiği davalarda bile uygulanmalı ve zarar nedenselliği yoluyla, yatırımcının gerçek bir zarara uğradığını kanıtlaması beklenmelidir ${ }^{62}$. Mahkeme bu noktada normatif zararın tazminat yükümlülüğüne yol açmayacağını ancak gerçek zararın tazmininin gerek kanunen gerekse de içtihat hukuku ile geliştirilen ilkeler sebebiyle istenebileceğinin mümkün olduğunu belirtmiştir ${ }^{63}$.

57 Bölge Temyiz Mahkemesinin 9. Dairesi, satın alma gününde menkul kıymetin fiyatının yapay olarak yüksek olduğunun iddia edilmesi ve ispatlanmasının tek başına zarar nedenselliği ve de zararın doğduğunun ispatlanması için yeterli saymaktadır, Broudo v Dura Pharmaceuticals, Inc. 339 F.3d 933 (9th Cir., 2003), s. 938.

58 Dura Karan, s. 342 ve s. 347: “... the 'artificially inflated purchase price' is not itself a relevant economic loss."

59 Dura Kararı, s. 342.

60 Bu açıdan Yüksek Mahkeme, menkul kıymet hile davasının, common-law' daki hile (deceit) ve hukuka aykıı açıklama (misrepresentation) davalarına benzediğini itiraf etmektedir, Dura Kararı, s. 343-344.

${ }_{61}$ Mahkeme bu hususta hakimlerce oluşturulan menkul kıymet hilesi davalarının common-law hilesi temeline ve ayrıca davacının gerçek zararını kanıtlamasını gerektiren ilkeye dayanması sebebiyle 9. Dairenin kararının diğer temyiz mahkemelerince reddedilmesinin çok da şaşırtııı olmadığını vurgulamıştır: "Given the common-law roots of the securities fraud action (and the common-law requirement that a plaintiff show actual damages), it is not surprising that other Courts of Appeals have rejected the Ninth Circuit's "inflated purchase price" approach to proving causation and loss", Dura Kararı, s. 344. Mahkeme aynı kararında, sermaye piyasası hukukunun temel amacı olan yatırımcının piyasaya duyduğu güveninin korunması için getirilen menkul kıymet hilesi davalarının amacının gerçek zararları gidermek olduğunu vurgulamıştır: “... but to protect them against those economic losses that misrepresentations actually cause.”, Dura Karar1, s. 345.

62 Robbins v. Koger Properties, Inc. 116 F.3d 1441 (11th Cir. 1997), s. 1448; NIELSEN/PROWSE, s. 18.

63 Yüksek Mahkeme burada menkul kıymet hilesi davasında davacının sadece ve yalnızca ekonomik zararının ve nedensellik bağının geleneksel anlayışa uygun ve yeterli bir şekilde kanıtlanması ile zararını tazmin edilebileceğini belirtmektedir. Mahkeme ayrıca 1934 tarihli Menkul Kiymetler Borsası 
Kural 10b-5'e dayanan hile davalarında zarar nedenselliğinin kanıtlanmasının aslında geleneksel inanç ölçütü (reliance) ile de bağdaştığ 1 ve buradaki zararın da davacı yatırımcının gerçekten katlandığı zarar olması gerektiği, yapay fiyattan işlem yapma görüşünü destekleyen Fox tarafindan da kabul edilmiştir ${ }^{64}$. Dolayısıyla zararın doğması henüz olasılıkla ifade ediliyorken ve malvarlığında gerçek bir azalma görülmezken, fiyatı etkileyen değişen ekonomik beklentiler veya koşullar, yatırımcı beklentileri, firma veya sektöre bağlı olgular veya fiyat dalgalanmaları gibi diğer etkenler de düşünüldüğünde hukuken bir zararın doğması söz konusu olamaz ${ }^{65}$. Bir menkul kıymetin ilk işlemi ile ters işlemi arasındaki süre ne kadar uzarsa, hukuka aykırı kamuyu aydınlatmadan ziyade diğer etkenlerin zarara sebep olma olasıllğ $\operatorname{artar}^{66}$. Nitekim yapay fiyattan işlem yapan yatırımcının ileri sürdüğü olası zararı, halihazırda elinde bulunan aynı değerdeki paylar sebebiyle dengelenmiştir ${ }^{67}$. Dava sonucunda ise davacı yatırımc1 da yükselen fiyatların, kamuya yanlış, yanıltııı veya eksik bilginin açıklandığının ortaya çıkmasından sonra düştügünü kanıtlayamadığı için haksız bulunmuştur ${ }^{68}$.

Federal Yüksek Mahkemeye göre sadece kamunun yanıltılması sonucu yapay fiyatlardan alım yapılması ile zararın meydana geldiği kabul edilirse firsatçı ve temelsiz tazminat davalarının hukuken önünün açılmasına sebebiyet verilmiş olacaktır $^{69}$. Bu durumda ilkesel olarak zarar esasen yanıltıcı şekilde yükselmiş fiyatlardan alım yapılması anında değil piyasanın yanıltıcı veya eksik açıklamaya tepki vermesi sonucu fiyatların düştüğü anda meydana gelmektedir ${ }^{70}$. Ancak piyasada yanlış veya eksik açıklamanın yapıldığının ortaya çıkmasına rağmen fiyatların buna tepki vermemesi söz konusuysa artık zararın doğduğundan bahsedilemez. Mahkemenin buradaki yorumu ikinci görüşte tanımlanan zarar kavramıyla örtüşmektedir; ancak kararda yatırımcının, kamunun yanlış, yanıltıcı

Kanunu §21D-(b)(4) hükmünün ve common-law hilesi davasında kabul edilen geleneksel ilkelerin de bu sonucu gerektirdiğini belirtmektedir, Dura Kararı, s. 346.

64 FOX, s. 511-512.

65 MANAVGAT, (2016), s. 250; Dura Kararı, s. 343.

66 Dura Kararı, s. 343.

67 Dura Kararı, s. 342.

68 Dura Karan, s. 348.

69 Dura Karar1, s. 346-348; ve s. 345: “... not to provide investors with broad insurance against market losses, but to protect them against those economic losses that misrepresentations actually cause". Ayn1 doğrultuda bkz. Supreme Court of United States, Basic, Inc. et al. v. Levinson et al. (No. 86-279) 485 U.S. 224 (1988), (Dissenting Opinion of Justice White and O'Connor) s. 252: “A nonrebuttable presumption of reliance ... would effectively convert Rule 10b-5 into 'a scheme of investor's insurance.."

70 MANAVGAT, (2016), s. 242. 
veya eksik bilgilendirilmesi sonucu yatırım kararı almasını ifade eden işlem nedenselliği dışlanmıştır ${ }^{71}$. Yatırımcı hukuka aykırı bilgilendirmeden haberdar olmadan, tamamen kendi başına yatırım kararı almış ve zarara uğramışsa, bu durumda her iki görüsse ve Mahkemeye göre bu yatırımcının zararının tazmin edilmesi gerekir.

Bir yatırımcının yapay yüksek fiyattan bir pay satın aldıktan sonra olumsuz gerçek bilginin açıklanmasını takiben o payın fiyatının düşmesi halinde paylarını satmayan yatırımcının fiyatlar eski seyrine ulaştıysa zararının tazmin edilmesi, ödüllendirilmesi anlamına gelir ${ }^{72}$. Yine benzer şekilde, halihazırda pay sahibi olan mevcut yatırımcının, hukuka aykırı açıklamadan sonra fiyatlar yükselmesine rağmen payını satmaması durumunda olumsuz gerçek bilginin açıklanması ile fiyatların satın alma fiyatının altına düşmesine rağmen yine satmayıp payları elinde tutması ve en nihayetinde fiyatların eski seyrine ulaşması sonucunda herhangi bir zarara uğradığı söylenemez. Dolayısıyla sonrasında Dura kararını yorumlayan ve genişleten federal bölge mahkemeleri, bir payın fiyatının düzeltici açıklama öncesindeki fiyata ulaştı̆̆ veya onu aştığı hallerde davacının ekonomik bir zarara uğramadığı; dolayısıyla davacının iddia ettiği hilenin yaklaşık ne kadar zarara sebebiyet verdiğini kanıtlayamayacağı yorumunda bulunmuşlardır ${ }^{73}$.

\section{TÜRK VE ABD HUKUKUNDA ZARARIN DOĞDUĞU AN}

\section{ABD Hukukunda Benimsenen Görüş}

ABD hukukunda sermaye piyasasinda tazmin edilmesi gereken zararın 1934 tarihli Kanun uyarınca açılabilecek sınıf davasında sorumluluğun ayrı bir unsuru olarak kabul edilmesi zaman almıştır. Menkul kıymet hilesi davalarının gerçek güven, nedensellik bağı ve zarar gibi bazı unsurlarının yargı tarafından geliştirilen karinelerle kolaylaştırılması ile yatırımcının zararının kolaylıkla tazmin edilmesi sonucunda sorumluluk davasının eziyetli bir dava haline geleceği ve ihraççların ciddi bir tazminat yükümlülüğüne maruz kalacağı korkusu oluşmuştur ${ }^{74}$. Bunun sonucunda Menkul Kıymetler Borsası Kanunu §10(b) hükmünün ihlalinin hukuki yollarla önceki gibi kolay bir şekilde dava edilmesini hem mahkemeler hem de

\footnotetext{
71 MANAVGAT, (2016), s. 252.

72 COFFEE, s. 538.

73 ARGANBRIGHT, s. 280.

74 Donald C. LANGEVOORT, "Deconstructing Section 11: Public Offering Liability in a Continuous Disclosure Environment," Law and Contemp. Probs. Cilt. 63, 2000, s. 51. Nitekim bu davalarm ABD ekonomisine zarar verdiği kabul edilmiştir, Elizabeth CHAMBLEE BURCH, "Reassesing Damages in Securities Fraud Class Actions" Maryland Law Review, Cilt 66, S. 2, s. 356.
} 
Kongre engellemiştir ${ }^{75}$. Tazminat davalarına ilişkin PSLRA ${ }^{76}$ ile sorumluluğun şartlarına bazı sınırlamalar getirilmiş ve bazı standartlar güçlendirilmiştir. ${ }^{77}$ Zarar nedenselliği gibi 1974'lü yıllardan beri Kural 10b-5'e dayalı tazminat davalarında mahkemeler tarafindan getirilen bazı şartlar da açı bir şekilde PSLRA ile yasalaştırılmıştır.

PSLRA'dan sonra yanlış, yanıltıcı veya eksik bir esaslı bilginin davalı tarafindan kasten açıklanması dolayısıyla Türk hukukundaki anlayışa da uygun olarak ekonomik anlamda bir zarara uğradığını ispat eden yatırımcı, zararını tazmin edebilecektir $^{78}$. Nitekim menkul kıymet hilesine ilişkin açılacak davanın şartları, esaslı bir bilginin yanlış, yanıltıcı veya eksik bir şekilde açıklanması, davalının kusurunun bulunmas1 ${ }^{79}$, işlem nedenselliği (transaction causation) ${ }^{80}$, ekonomik bir zarar ve zarar nedenselliği olarak belirtilmektedir ${ }^{81}$. PSLRA, Kural 10b-5'e dayanan tazminat davasının bir şartı olarak ekonomik zararı açıkça öngörmese bile Federal Yüksek Mahkeme, çok önemli bir karar olan Dura kararında ${ }^{82}$ bunu ayrı ve temel bir şart olarak değerlendirmiştir.

Ekonomik zarar, ABD hukukunda uzun zamandır kabul edildiği üzere geleneksel ölçüte göre, yatırımcının bir menkul kıymete ödediği fiyatı ve o menkul kıymetin satın alma anındaki varsayımsal gerçek değerinin farkının, o menkul kıymete ödenen fiyat ile satma anındaki varsayımsal gerçek değeri

7515 U. S. Code, Title 15, Chapter 2B, §78j-(b): Regulation of the use of manipulative and deceptive devices; FENCHER/ TIPTON, s. 33.

76 Private Securities Litigation Reform Act of 1995, Public Law No. 104-67.

77 John ARGANBRIGHT, "No Loss, No Problem: How the Second Circuit Altered Dura and the Concept of Economic Loss in Securities Fraud Cases in Acticon AG v. China North East Petroleum Holdings, Ltd.”, Seton Hall Law Review, Cilt. 44, 2014, s. 282.

7815 U. S. Code, Title 15, Chapter 2B, §78u-4(b)(4): Private securities litigation.

79 Kredi derecelendirme kuruluşlarına veya hakim ortağa karşı açılacak tazminat davaları açısından bilerek veya dikkatsizce kredi riskini değerlendirirken makul bir araştırma yürütmemiş veya ihraççı ve aracı kurumdan bağımsız kaynaklardan makul bir doğrulama sağlamamış olması hile davasının kusur şartını sağlamaya yetecektir.

80 Bir yatırımcının hukuka aykıı olarak açıklanan esaslı bilgiye gerçekten güvenerek işlem yaptığına ilişkin kanıtlanması gereken nedensellik bağıdır. Nedensellik bağı özellikle ABD hukukunda menkul kıymet hilesi davalarında işlem nedenselliği ve zarar nedenselliği olarak ikiye ayrılarak incelenmektedir. Nedensellik bağının zarar nedenselliği türünde, yatırımcının meydana gelen zararının hukuka aykırı bilgi veya belgeden kaynaklandığını ispatlaması gerekirken, işlem nedenselliği türünde, kamuyu aydınlatma belgesini gerçekten okumuş ve içerdiği bilgilere inanarak işlem yapmış olması aranmaktadır.

8115 U. S. Code, Title 15, Chapter 2B, §78u-4(b)(4): Private securities litigation.

82 Dura Pharmaceuticals, Inc. v. Broudo (No. 03-932) 544 U.S. 336 (2005), s. 341-342. 
arasındaki farkından çıkarılmasıyla bulunur ${ }^{83}$. Ekonomik zarar, zarar nedenselliği şartı ile birbirine bağlıdırlar; çünkü davacı yatırımcı öncelikle ekonomik bir zarara uğradığını kanıtlamalı ve sonra da uğradığı zararın hukuka aykırı yapılan açıklama sonucu değişen fiyatlardan kaynaklandığını kanıtlamalıdır ${ }^{84}$. Davacı ayrıca menkul kıymetin fiyatında, söz konusu yanlışlık veya eksiklikten veya açıklama yapılmamasından kaynaklanan artış veya azalış sonucu gerçekleşen zararının miktarı ile bu hukuka aykırılık olmasaydı gerçekleşecek borsadaki genel değişim miktarını davada birbirinden ayırt etmelidir ${ }^{85}$.

Sonuç olarak zarar kavramına ilişkin ayrıntılı olarak yapılan tartışmalar neticesinde ABD hukukunda fark görüşü benimsenmiştir. Yatırımcının Menkul Kıymetler Kanunu §11 ve 12 hükümleri uyarınca talep edebileceği zararı, menkul kıymetin halka arz edilen fiyatını geçmeyecek şekilde o menkul kıymete ödenen satın alma fiyatı ile; o menkul kıymet hala elindeyse dava tarihindeki fiyatı, dava açılmadan önce elden çıkarıldıysa satıldığı tarihteki fiyatı veya mahkeme kararı verilmeden önce, ancak dava açıldıktan sonra elden çıkarıldıysa satıldığı tarihteki fiyatı arasındaki farktır ${ }^{86}$.

\section{Türk Hukukunda Benimsenen Görüş}

\section{a. Borçlar Hukukunda}

Türk borçlar hukukuna bakıldığında genel hükümler uyarınca zarar kavramının tespitinde haksız fiiller için fark görüşünün doktrinde hakim olduğu görülmektedir $^{87}$. Fark görüşüne göre düşünüldüğünde, hukuka aykırı bilgilendirme

83 Zararı ABD haksız fiil hukukunda geleneksel olarak kabul edilen bu ölçüte göre hesaplanması, 1943 tarihli Menkul Kıymetler Borsası Kanunu §10(b) hükmüne dayanarak açılan davalarda uzun zamandır uygulanmaktadır, Peri NIELSEN/Stephen PROWSE, "Securities Litigation: Dura's Impact on Damages" Insights, Cilt 22, S. 7, 2008, s. 16.

84 ARGANBRIGHT, s. 282.

85 FENCHER/ TIPTON, s. 33; NIELSEN/PROWSE, s. 19. Bu görüş, Dura davasından sonra In re Intelligroup Sec. Lit. [468 F. Supp. 2d 670 (D.N.J. 2006)] davasında uygulama bulmuş ve davacı yatııımcıların, zararlarının hukuka aykırı açıklama dışında başka hiçbir unsurdan kaynaklanmadığını da ispatlaması gerekmiştir,

86 Ancak burada 1933 tarihli Menkul Kıymetler Kanunu §11 hükmüne dayanarak açılacak davalarda istenebilecek zarar, hukuka aykırı açıklamadan başka bir sebebe dayanan zararları kapsamaz; dolayısıyla bu hükme göre açılacak davalardaki zarar kavramı, 1934 tarihli Menkul Kıymetler Borsası Kanunu §10(b) hükmüne göre açılacak davalardaki zarar kavramı ile benzerdir, NEILSEN/PROWSE, s. $23-24$, dn. 2.

87 EREN, s. 545 vd.; OĞUZMAN/ ÖZ, Cilt II, s. 38; Haluk NOMER, Haksız Fiil Sorumluluğunda Maddi Tazminatın Belirlenmesi, İstanbul, 1996, s. 8; TEKINAY, s. 736; İNAL, s. 670; Burak ADIGÜZEL, Sermaye Piyasası Hukuku, 2. Baskı, Adalet, Ankara, 2018, s. 120. 
sonucu oluşan yapay fiyatlardan alım veya satım yapıldığında zarar meydana gelmez. Borçlar hukukuna göre zarar öncelikle kural olarak gerçek bilginin kamuya açıklanmasını takiben fiyatların değişmesi ile ters işlem yapılmazsa yapay fiyat ve değişen fiyat arasındaki fark dolayısıyla malvarlığında meydana gelen azalma sonucu oluşur. Nitekim Kütükçü, bir sermaye piyasası aracının ilk halka arzında yatırımcının ödediği fiyatla düzeltici açıklamadan sonra değişen fiyat arasındaki farkın zararı oluşturduğunu düşünmektedir ${ }^{88}$. İkinci olarak eğer gerçek ve doğru bilginin kamuya açıklanmasının ardından ters işlem yapılırsa bu durumda zarar, ilk işlemin yapıldığı ve yatırımcı tarafından ödenen yapay fiyat ve ters işlemin yapıldığı fiyat arasındaki farktan oluşur.

Genel hükümler uyarınca zarara sebebiyet verebilecek diğer bir durum da hukuka aykırı bilgilendirme yapılmadan önce alım veya satım işleminin yapılması ancak ters işlemin hukuka aykırı bilgilendirme sonrasında yapılması durumudur. $\mathrm{Bu}$ durumda her iki işlemin yapıldığı fiyatlar arasındaki fark, zarar olarak kabul edilebilecektir; ancak ABD hukukunda ilk işlem hukuka aykırı bilgilendirmeden önce ve ondan bağımsı olarak yapıldığ 1 için sorumluluğun doğmayacağ 1 belirtilmiştir ${ }^{89}$. Söz konusu içtihat, ABD hukukundaki Kural 10b-5'in hukuka aykırı bilgilendirme ile alım veya satım işlemi arasında bir bağlantı bulunmasını gerektirmesi (in connection with) sebebiyle; ayrica sinıf davaları (class actions) yoluyla sorumluluğun genişletilmesini engellemek amacıyla geliştirilmiştir ${ }^{90}$.

Ancak yatııımcı, gerçek ve doğru bilginin kamuya açıklanmasının hemen ardından ters işlemi yaptığında oluşacak fark ile bir süre bekledikten sonra ters işlemi yaptığında oluşacak fark da aynı olmayacaktır ${ }^{91}$. Benzer şekilde, yatırımcının açtığ tazminat davasında hükmün verilmesine kadar geçecek sürede sermaye piyasası aracının değeri eski seyrine ulaşmışsa artık yatırımcının zararının olduğundan söz edilemez ${ }^{92}$. Nitekim hala yatırımcının elinde bulunan bir sermaye piyasası aracının değerinin düşmesinde olduğu gibi normatif zararların gerçek anlamda zarar olmadığı; ancak zarar tehlikesinin olduğu durumlarda ilgililerin sorumluluğu doğmamaktadır ${ }^{93}$.

88 Doğan KÜTÜKÇÜ, Sermaye Piyasası Hukuku, 1. Cilt, Beta, İstanbul, 2004, s. 240.

89 Gurary-Winehouse; Roots Partnership-Lands' End, Inc.; Binder-Gillespie; Kaplan-Utilicorp United, Inc. kararları

90 MANAVGAT, (2016), s. 258.

91 MANAVGAT, (2016), s. 257.

92 MANAVGAT, (2016), s. 259.

93 Cengiz KOÇHISARLIOĞLU, “Objektif Sorumluluğun Genel Teorisi” Dicle Üniversitesi Hukuk Fakülttesi Dergisi, Cilt 2, Say1 2, 1984, s. 284. Kusursuz sorumlulukta dahi, zarar doğmadan zarar 


\section{b. Sermaye Piyasası Hukukunda}

SPKn m. 32 uyarınca yatırımcının, tazmin edilebilecek zararı, kamuyu aydınlatma belgesinde yer alan eksik, yanlış ya da yanıltıcı bilgiye dayanarak aldığ bir yatırım kararı sonucunda malvarlığında meydana gelen aktif bir azalmadır. Zarar, öncelikle sermaye piyasası aracının satın alındığı andaki gerçek değeri ile satın alanın bu araç için yapay fiyattan ödediği bedel arasındaki farktan oluşan maddi zarardır ${ }^{94}$ ve dolayısıyla yatırımcının malvarlığındaki aktif bir azalma olarak düşünülmelidir. Sermaye piyasası aracının gerçek değeri belirlenirken gerçek ve doğru bilginin düzeltici açıklama ile kamuya açıklanmasının ardından değişen fiyatların hesaplamada kullanılması, SPKn m. 32/6'daki zamanaşımının bu açıklama ile başlayacağı hükmüyle örtüşmektedir ${ }^{95}$. Yani genel hükümlerin aksine, alım veya satım işleminin yapay fiyat üzerinden yapılması suretiyle başkaca bir işleme gerek olmaksızın malvarlığında bir azalma meydana gelmesi sebebiyle tazminat sorumluluğunun doğduğu kabul edilmez ${ }^{96}$. Bu hususun önemi pay teminatlı kredili menkul işlemlerinde, payın fiyatının düşmesi ile teminat miktarında azalma olan yatıımıının bu düşüş ile ortaya çıkan zararını karşılama hakkının doğmasıyla ortaya çıkmaktadır ${ }^{97}$.

Buradaki zarar kavramı, yukarıda açıklanan ve yapay fiyatlar üzerinden işlem yapılmasıyla meydana geldiği savunulan birinci görüşteki zarar kavramından farklıdır. Nitekim zararın işlem yapılan yapay fiyat ile hukuka aykırı açıklama yapılmasaydı oluşacak varsayımsal fiyat arasındaki farktan meydana gelmediği; piyasada oluşan gerçek fiyatlar üzerinden hesaplama yapıldığ 1 görülmektedir ${ }^{98}$. Dolayısıyla sermaye piyasası hukukundaki zarar kavramı, genel hükümlerdekinden farklıdır ve kapsamı da daha dardır. SPKn m. 32/4'te her ne kadar nedensellik bağına ilişkin özel bir düzenleme getirilmiş olsa da, aynı

tehlikesi ile tazminat yükümlülüğü doğmamaktadır. Nitekim fiyatların düşmesi ile elindeki sermaye piyasası aracının fiyatı azalan bir yatırımcı, düzeltici açıklamadan sonra fiyatların eski seyrine ulaşması sonucunda zarara uğramamıştır. Ancak fiyatlar eski seyrine ulaşana dek, elindeki aracı satmaya niyetlenen yatırımcı zarar görme tehlikesiyle karşı karşıyadır. Ayrıca Alman hukukunda kabul edilen normatif zarar kavramı Türk hukukunda şartları varsa sadece maddi zarar olarak değerlendirilebilir. Ancak bu durumda normatif zararın maddi zarar çerçevesinde talep edilebilmesi mümkün değildir.

94 KARA, s. 149; ADIGÜZEL, s. 120.

95 MANAVGAT, (2016), s. 255.

96 MANAVGAT, (2016), s. 258. Bu noktada normatif zararın, malvarlığında gerçek zarar şeklinde ortaya çıkmasıyla tazmin edilebileceğine ilişkin olarak bkz. KILIÇOĞLU, s. 396 ve 397.

97 MANAVGAT, (2016), s. 258-259.

98 MANAVGAT, (2016), s. 261; KESKIN, s. 114-115. 
maddede zararın tanımında ne gibi ölçütlerin kullanılması gerektiği de açıça belirtilmiştir ${ }^{99}$.

SPKn m. 32'deki zararın, genel hükümlerden ayrılan en önemli hususu, SPKn m. 32/4'ten anlaşıldığı üzere hukuka aykırı açıklamadan sonra belirli süreler içerisinde alım veya satım işlemlerinin yapılmasının ardından, düzeltici açıklama sonucunda yalnızca ters işlemin yapılmasından sonra doğan zararların tazmin edilmesidir $^{100}$. Öncelikle alım veya satım işleminin yanlış, yanıltıcı veya eksik bilgi içeren kamuyu aydınlatma belgelerinin açıklanmasından sonra belirli süreler içerisinde yapılması gerekmektedir. Bu sürelere illiyet bağının düzenlendiği bu fikrada işaret edilmiş ve izahnamenin geçerlilik süresi boyunca, diğer kamuyu aydınlatma belgelerinin ise kamuya açıklandığı tarihten hemen sonra ilk alım veya satım işleminin yapılması gerektiği belirtilmiştir. İkinci olarak ise ters işlemin yanlış, yanılııı veya eksik bilgiler içeren kamuyu aydınlatma belgelerinin açıklanmasından sonra yapılmış olması gerekmektedir.

Gerek ihraççı şirket tarafindan resen gerekse de Kurulun müdahalesi sonucu kamuya gerçek ve doğru bilgi açıklanabilir; ancak hangi yöntemle açıklanırsa açıklansın piyasada bu bilginin algılanması ve fiyatlara yansıması zaman alacaktır. $\mathrm{Bu}$ sürecin sonunda fiyat değişikliğinin yegane sebebinin doğru ve gerçek bilginin herhangi bir yöntemle kamuya duyurulmasıyla hukuka aykırı aydınlatmanın etkisinin ortadan kalkması olduğu her zaman söylenemez ${ }^{101}$. Çünkü fiyatın o süreçte meydana gelen başka bir olaydan veya açıklamadan etkilenmesi ve hukuka uygun kamuyu aydınlatma sonucu beklenenden az bir artış veya azalma göstermesi de mümkündür. Dolayısıyla fiyattaki değişmelerin sınırlarını belirlemek ve SPKn m. 32/4'te gösterilen açıklamadan hemen sonraki fiyat değişimini tespit edebilmek için fiyatın BIST endeksleriyle paralel bir endekse oturması yeterli olabilmektedir ${ }^{102}$.

Diğer taraftan buradaki zarar, yatırımcının herhangi bir kazançtan mahrum kalması yani kar kaybı şeklinde de olabilir. Özellikle sermaye piyasası aracının gerçek değerinin yüksek olduğu durumda, kamuya hiç açıklanmayan ya da yanlış, yanıltıcı veya eksik açıklanan bilgi dolayısıyla yatırımcının elindeki sermaye piyasası aracını düşük fiyatla satması halinde gerçek durum bilinse daha yüksek fiyata satabileceği kardan mahrum kalması buraya örnek olarak verilebilir ${ }^{103}$.

\footnotetext{
99 MANAVGAT, (2016), s. 254; KESKIN, s. 114-115.

100 MANAVGAT, (2016), s. 254; KESKIN, s. 115.

101 MANAVGAT, (2016), s. 255; KESKIN, s. 116.

102 MANAVGAT, (2016), s. 255.

103 KARA, s. 150.
} 
Ancak bunun ilgili maddedeki sorumluluğun genişletilmesi olarak kullanılmaması gerekmektedir ${ }^{104}$. Örneğin yatırımcının, kamuyu aydınlatma belgesinde yer alan bilgilerden ötürü, satın almaya niyetlendiği sermaye piyasası araçlarını satın almadığ 1 için bir kazanç mahrumiyetinin bulunduğu iddiası dinlenilmemelidir ${ }^{105}$.

Zararın kapsamı belirlenirken yatırımcının malvarlığında meydana gelen her azalmanın değil, belirli azalmaların dikkate alınması gerekir; nitekim yatırımıının malvarlığında esasen SPKn m. 32 uyarınca tazmin edilmesi gerekmeyen bazı azalmalar olabilir. Zarar kapsamına dahil olmayacak azalmalar açısından kural olarak bilginin esaslı olup olmadığını ve bu bilginin ne kadar zarara sebep olduğunu, yargı öngöremeyeceği için, piyasa belirler ve yargı sistemi de bu zararın nasıl ve kimlerce tazmin edileceğine karar verir ${ }^{106}$. Ancak piyasa, hukuka aykırı açıklamaya tepki vermediyse veya tamamen farklı bir sebeple tepki verdiyse zarar oluşmamış olabilir; oluştuysa bile belirlenemeyebilir ${ }^{107}$. Bu durumların bir kısmı asıl olarak illiyet bağını kesen sebeplerin düzenlendiği 5. fikrada bentler halinde sayılmıştır, illiyet bağının kesilmesi ile aslında zararın hiç doğmadığı hallerin veya bu maddeye göre tazmin edilmeyecek olan zararların belirlendiği görülmektedir.

Öncelikle SPKn m. 32/5/b hükmünde de ifade edildiği üzere, zarar görenin rızası dahilinde malvarlığında meydana gelen azalmalar zarar olarak kabul edilmez $^{108}$. Ayrıca SPKn m. 32/5/a ve ç'de ifadesini bulduğu üzere yatırımcının kamuyu aydınlatma belgesinin konusu olan sermaye piyasası aracına ilişkin zararı, bu belgede yer alan hukuka aykırı açıklamadan veya hiç açıklama yapılmamasından farklı bir sebeple meydana gelmiş olabilir. SPKn m. 32'deki sorumluluk hali, yatırımcının kamuyu aydınlatma belgesinde yer alan bilgilerin doğruluğuna güvenerek yatırım yaptığı durumlarla sınırlıdır. Benzer şekilde ABD hukukunda da Menkul Kıymetler Kanunu §11 hükmündeki zararın herhangi bir miktarının, kayıt belgesinin yanlış, yanıltıcı veya eksik bir bilgi içeren ve sorumluluk doğuran kısmından kaynaklanan değer azalmasından farklı bir sebeple meydana geldiği kanıtlanırsa, o miktar tazmin edilmez.

\footnotetext{
104 İNCEOĞLU, s. 134.

105 İNCEOĞLU, s. 134.

106 John C. COFFEE, "Causation By Presumption? Why the Supreme Court Should Reject Phantom Losses and Reverse Broudo?" Columbia Law and Economics Working Paper, No. 264, 2005, s. 533.

107 COFFEE, s. 533; KESKIN, s. 116.

108 OĞUZMAN/ÖZ, Cilt II, s. 40, para. 115.
} 
Buna ek olarak SPKn m. 32/5/c'de de belirtildiği gibi bir yatırımcı hukuka aykırı kamuyu aydınlatmadan önce bir sermaye piyasası aracına ilişkin alım veya satım işlemi yapmış ve düzeltici açıklamadan sonra fiyatlar normal seyrine ulaşana kadar söz konusu araca ilişkin ters işlem yapmamış ise bu yatırımcının zarara uğradığı da ileri sürülemez. Nitekim SPKn m. 32 uyarınca gerçek ve doğru bilginin ortaya çıkması sonucu sermaye piyasası aracının değeri düşmüş ancak yatırımcının bu aracı sattığı sırada dış etkenler sonucu piyasa fiyatı yeniden yükseldiği için yatırımcının malvarlığında bir azalma olmamışsa, burada yine zarardan bahsedilemeyecektir ${ }^{109}$. ÖzellikleAlman hukukunda tartışılan ve normatif zarar olarak adlandırılan kavram uyarınca, yatırımcının, hala elinde bulunan sermaye piyasası aracının fiyatının hukuka aykırı açıklamalar sonucu düşmesi nedeniyle bu aracın uğradığı değer kaybı, Türk hukukundaki zarar kavramına girmemektedir. Malvarlığında herhangi bir azalma belirtisi görülmemesine rağmen yatırımcının elindeki sermaye piyasası aracının değerinde meydana gelen geçici azalmalar, eğer yatırımcı ters işlem yaparak gerçek bir zarara uğramadıysa, bu maddeye göre tazmin edilmez.

Son olarak da kamuyu aydınlatma belgelerinde hukuka aykırı bir bilginin yer almasına rağmen ilgili sermaye piyasası aracına ilişkin yatırımcının işlem yaptığı fiyat, düzeltici açıklamadan sonra oluşan gerçek fiyattan her durumda daha yüksekse zararın oluştuğundan söz edilemez. Benzer sebeple ABD hukukunda da Menkul Kıymetler Kanunu §11 hükmü uyarınca dava veya satın alma tarihindeki fiyat, sermaye piyasası aracının halka arz edildiği fiyattan daha fazla ise yatırımcının zararından bahsedilemez ${ }^{110}$. Sonuç olarak sermaye piyasası hukukunda tazmin edilmesi gereken zarar kavramı genel hükümlere nazaran daha dar kapsamlıdır.

\section{Zararın Doğduğu Ana İlişkin Türk Hukukunda Benimsenen Görüşün, Zararın ve Tazminatın Belirlenmesine Etkisi}

\section{a. Zararın Belirlenmesi}

Zarar miktarını aşan tazminata hükmedilemeyeceği ve zarar tazminat davasında hükmedilecek tazminatın üst sınırını oluşturacağı için zararın, doğduğu ana göre belirlenmesi önemlidir ${ }^{111}$. Zararın belirlenmesinde malvarlığının zarar

109 KARA, s. 150; MANAVGAT, (2016), s. 256.

110 Tolga AYOĞLU, Sermaye Piyasası Hukukunda Halka Arz Kavramı ve Halka Arza Aracılık Sözleşmeleri, Vedat, İstanbul, 2008, s. 138-139; Allan HORWICH, "Section 11 of the Securities Act: The Cornerstone Needs Some Tuckpointing" The Business Lawyer, Cilt 58, 2002, s. 13.

111 OĞUZMAN/ÖZ, CiltII, s. 85, no. 255; KILIÇOĞLU, s. 533; Haluk TANDOĞAN, Türk Mes'uliyet Hukuku, 2. Bask1., Vedat, İstanbul, 2010, s. 261; TEKINAY, s. 785; İNAL, s. 203. 
verici olay veya işlemden önceki ve sonraki durumu arasındaki fark göz önüne alınarak bir değerlendirme yapılır ${ }^{112}$. Türk borçlar hukuku doktrininde benimsenen fark teorisi uyarınca zararın hesaplanmasında istisnai olarak bir kanun hükmüyle öngörülmüssse objektif ${ }^{13}$ aksi halde somut olay bazında uygulanan sübjektif hesaplama yöntemleri kullanılır ${ }^{114}$. Malvarlığı zararları açısından Türk ve İsviçre hukukundaki hakim görüş uyarınca hakimin karar vereceği tarihin esas alınarak zararın hesaplanması söz konusudur; ancak uygulamada Yargıtay, zarar verici olay veya işlemin gerçekleştiği tarihi zararın hesaplanmasında esas almaktadır ${ }^{115,116}$. Nitekim bu tarihte halihazırda gerçekleşmiş zararların hesaplanması mümkün olduğu için kural olarak zararın hesaplanabilir olması gerekmektedir; dolayısıyla henüz gerçekleşmemiş zararların tazmini kural olarak istenemez.

Fiili zararın genel hükümlere göre hesaplanması malvarlığının zarar verici olay veya işlemden önceki durumu ile sonraki durumu arasındaki farkın hesaplanması suretiyle yapilır ${ }^{117}$. Zararın mevcudiyeti konusunda ispatta bir zorluk yaşanmasa bile zararın tam anlamıla belirlenmesi ve hesaplanması her zaman mümkün

112 Budeğerlendirmedezararauğrayanşeyin, zarargören için taşıdığı ekonomik değervekişinin malvarlığının diğer unsurlarıyla birlikte meydana getirdiği bütünlük göz önüne alınır, EREN, s. 546. TBK m. 50/2 uyarınca zararın varlığı ve miktarının belirlenmesine yönelik ispata ilişkin delillerin takdirinde hakim geniş bir takdir yetkisine sahiptir. Ancak bu hükmün uygulama alanı daha çok bedensel bütünlüğün ihlali ve ekonomik geleceğin sarsılması halidir; bkz. EREN, s. 748.

113 Objektifhesaplama yönteminde bir şeyin belirli bir anda herhangi bir etkiden uzak olarak serbest piyasada belirlenen değeri esas alınır, EREN, s. 761-762; TANDOĞAN, s. 273. Şeye verilen zarar için genel olarak objektif hesaplama yönetiminin kullanılmasına yönelik olarak bkz. INAL, s. 204-205.

114 Kural olarak Türk ve İsviçre hukukunda sübjektif hesaplama yöntemi kullanılarak zarar görenin somut malvarlığının hangi kayıplara uğradığı tespit edilir, EREN, s. 762.

115 Beden bütünlüğünün ihlalinden doğan zararlarda hüküm tarihinin esas alınacağı TBK m. 75 ’ten anlaşıısa da malvarlığında meydana gelen zararın hesaplanacağı tarih doktrinde tartışmalıdır. Bedensel zararlar için TBK m. 75’te öngörülen karar tarihi uygulamasından hareketle malvarlığı zararlarının hesaplanmasında da karar tarihi esas alınır, EREN, s. 748. Benzer görüş için bkz. TANDOĞAN, s. 265; TEKINAY, s. 812-813; İNAL, s. 203.

116 Yargitay 4. HD, 2.12.1972 tarih ve 7606/10156 sayılı Karar. Tandoğan'a göre, hüküm tarihinin esas alınmasının mümkün olmadığı durumlarda zarar verici olay tarihi esas alınarak zarar hesaplaması yapılır; ancak olay tarihinden itibaren faize de hükmedilmelidir, TANDOĞAN, s. 265-266. Benzer doğrultudaki görüş için bkz. Kılıçoğlu, s. 524-525. Burada Kilıçoğlu, enflasyon nedeniyle, zarar verici olaydan sonraki bir tarihte dava açan zarar görenin, olay anına göre hesaplanan tazminat ile zararının karşılanması mümkün olmazsa karar tarihinden itibaren gecikme faizi isteyebileceğini; bu faiz de zararııın karşılanmasına yetmezse, TBK m. 122'ye dayanarak gecikme faizi ile karşılanamayan munzam zararını talep edebileceğini belirtmektedir.

117 Zararın hesaplanmasında zarar verici olay meydana gelmeseydi kişinin malvarlığının ne durumda olacağının tespit edilmesi, farazi ve özel bir değerlendirmeyi gerektirir ki bu en çok yoksun kalınan karın belirlenmesinde problem oluşturmaktadır, EREN, s. 546; TANDOĞAN, s. 263. 
olmayabilir ${ }^{118}$ ve bu durumda TBK m. 50/2 uyarınca hakim olayların olağan akış1 ve zarar görenin aldığı önlemleri değerlendirerek zarar miktarını hakkaniyete uygun bir şekilde takdir eder. Genel hükümlere göre zarar verici olay veya işlem aynı zamanda zarar gören açısından bir menfaat veya ekonomik anlamda bir fayda sağlamışsa doktrinde ve uygulamada kabul edildiği üzere bu miktarın da maddi zararın belirlenmesi esnasında düşülmesi gerekmektedir ${ }^{119}$. Aksine bir hüküm veya taraf iradesi bulunmaksızın zarar verici olayın zarar gören lehine ekonomik bir yarar sağladığı davalı tarafından kanıtlanırsa, zarar verici olayın uygun bir sonucu olan yararlar, maddi zarardan düşülür. Nitekim bu uygulama ile zarar görenin zenginleşmesi değil; zarar görenin "net zararının bulunması" amaçlanmaktadır ${ }^{120}$.

SPKn m. 32'ye göre tazmin edilmesi gereken zararın belirlenmesi, ters işlem görüşüne uygun olarak, yatırımcının işlem yaptığ 1 yapay fiyat ile ters işlemini yaptığ fiyat arasındaki farktır. $\mathrm{Bu}$ fark, yatırımcının hukuka aykırı bilgi açıklandıktan sonra ve bu sebeple sermaye piyasası aracına ilişkin alım veya satım işlemini yaptığı fiyat ile düzeltici açıklamadan sonra ters işlemini yaptığı fiyat arasındaki farkın matematiksel hesaplanması ile bulunur. Buradaki hesaplama oldukça nesnel ve net olmakla birlikte herhangi bir değerlendirmeyi gerektirmediği gibi olası bir tereddüde de yol açmaz. Sonuç olarak sermaye piyasası hukukunda benimsenen ters işlem görüşü, fiili zararın hesaplanmasını kolaylaştırır ve yukarıda açıklanan zorlukların doğmasını engeller.

\section{b. Tazminatın Belirlenmesi}

Hükmedilecek tazminat miktarının üst sınırını zarar oluşturacağından zararın doğum anının belirlenmesi, tazminatın da belirlenmesi açısından büyük önem arz etmektedir ${ }^{121}$. Tazminatın belirlenmesi açısından zararın doğduğu ana ilişkin Türk borçlar hukuku ve sermaye piyasası hukukunda benimsenen farklı görüşlerin bulunmasının bir etkisi bulunmamaktadır. Dolayısıyla bu konuda genel

118 zarar görenin hırsızın ne değerdeki eşyasını çaldığını ispatlayamaması gibi bazı hallerde haksız fiilin neden olduğu zararı, zarar gören davacının ispatlaması oldukça zor hatta imkansızdır, TANDOĞAN, s. 262.

119 EREN, s. 751-752. Denkleştirme uygulaması doğrudan bir kanun hükmünden kaynaklanmasa da bu uygulama, Alman ve İsviçre hukukunda fark teorisine dayandırılmıştır, TEKINAY, s. 791; TANDOGAN, s. 268. Sadece maddi zararın hesaplanmasında denkleştirme uygulanırken manevi zararlar açısından bu denkleştirme yapılamayacağı kabul edilmiştir, INAL, s. 211-213.

120 OĞUZMAN/ ÖZ, Cilt II, s. 89, no. 266; tazminatın belirlenmesinden ziyade, zarar görenin lehine bir durum olması sebebiyle uygulamada zararın hesaplanmasında resen denkleştirme yapıldıktan sonra gerçek zarar tespit edilmektedir, EREN, s. 751-752; Yargitay 4. HD. 31.03 .2004 tarihli ve 2003/14455 Esas ve 2004/4104 Karar sayll Kararı.

121 OĞUZMAN/ ÖZ, Cilt II, s. 114, no. 347. 
hükümlere göre yapılan açıklamalar sermaye piyasası hukukunda da geçerlidir. Genel hükümlere göre hakim TBK m. 51/1 uyarınca tazminatın kapsamını ve ödenme biçimini durumun gerekleri ve kusurun ağırlığını göz önüne alarak takdir ve tayin eder ${ }^{122}$. Tazminat miktarını belirlerken hakim borçlunun kusurunun ağılık derecesini ve durumun gereğini göz önüne alır ${ }^{123}$. TBK m. 52'de öngörülen bazı indirim sebepleri başta olmak üzere hakim belirli sebeplerle tazminat miktarından indirim yapabilmektedir ${ }^{124}$.

Tazminatın belirlenmesinde sermaye piyasası hukuku açısından farklı bir düzenleme getiren ${ }^{125}$ ABD hukukunda, 1934 tarihli Kanunun §21(D)(e) hükmüne göre davacı yatırımcıya ödenecek tazminatın tutarı, davacının gerçekten o sermaye piyasası aracı için ödediği fiyat ile doğru bilginin kamuya açıklandığı tarihten başlayarak doksan günlük dönemde hesaplanacak ortalama fiyat arasındaki farkı geçemez. Düzeltici açıklamanın hemen ardından piyasanın tepki vermesi gerekmediği gibi bu hüküm sayesinde kısa sürede yapılan piyasa düzeltmelerine

122 Tazminatın ödenme biçiminin nakden ödeme olacağ 1 şüphe götürmese de hakim, tazminat miktarının belirlenmesine ilişkin bir değerlendirme yapacaktır. Maddi tazminatı isteme hakkı alacak hakkı niteliğinde olup bu tazminatın ödenmesinde, aynen veya nakden tazmin mümkündür. Zararın nakden tazmin edilmesinde tazmin sermaye veya irat şeklinde gerçekleşebilir. Alman hukukunda BGB \$249 Abs. 1 hükmü ile kural olan aynen tazmine karşın Türk hukukunda hakimin takdiri doğrultusunda her iki tür de eşit derecede uygulamaya sahiptir.

123 BGB'de bu yönde bir hüküm bulunmamasına rağmen kanunumuzda bu yönde bir hüküm olması temel ilke olan kusur sorumluluğu ilkesiyle de uyumludur, OĞUZMAN/ ÖZ, Cilt II, s. 119-120, no. 370.

124 Tazminatın hesaplanmasında bazı kanunlarda öngörülen indirim sebepleri vardır. Zarar görenin zarara razı olması, zarar görenin ortak veya kişisel kusurunun bulunması, kusur sorumluluğunun hesaplanmasında zarar verenin kusurunun ağır veya hafif olması; veya somut olayın özelliklerine göre başka indirim sebeplerinin de bulunması mümkündür. İndirim sebeplerinden olan zarar verenin kusurunun derecesi, sözleşmesel sorumlulukta tazminat borcunun doğumuna etki etmezken, tazminat miktarının belirlenmesinde kural olarak önemli bir rol oynamaktadır. Ödenecek tazminatın miktarı ile zarar verenin kusurunun ağırlı̆ı doğru orantılıdır, ancak TBK m. 114/1'de sözleşme sorumluluğu açısından borçlunun her türlü kusurundan sorumlu olacağı belirtilmiştir. Haksız fiil sorumluluğunda ise zarar belirlendikten ve hesaplandıktan sonra tazminatın belirlenmesi aşamasında zarar verenin ağır kusuru, tazminat miktarının zarar miktarına eşit olmasına neden olabilir.

125 Zararın doğum anına ilişkin benimsenen herhangi bir görüşle ilgisi olmaksızın, Kanada hukukunda ihraççının kamuya yaptı̆̆ı hukuka aykırı açıklamalardan ötürü zarar gören yatıımcıya karşı sorumlu olacağı tazminat miktarı bir milyon Kanada Doları ve ihraççının piyasadaki paylarının değerinin \%5'in toplamını geçemez, Christopher C. NICHOLLS, "Civil Enforcement in Canadian Securities Law", Journal of Corporate Law Studies, Cilt 9, S. 2, 2009, s. 399. Benzer şekilde fark teorisinden kaynaklanmasa da tazminatın belirlenmesi açısından ABD hukukunda Menkul Kıymetler Kanunu §11 hükmü, aracı kurumun kendisi tarafindan ihraçtan önce üstlenilmeyen menkul kıymetin toplam fiyatını aşan zararlardan hiçbir şekilde sorumlu olmayacağını belirterek aracı kurumlar açısından sorumluluğun sınırını çizmiştir. Ancak, eğer ihraççıdan aracı kurum olması sebebiyle doğrudan veya dolaylı olarak bir menfaat sağlamışsa halka arz edilen menkul kıymetin toplam fiyatını aşmayacak şekilde doğacak zararlardan sorumlu olacaklardır. 
karşı sorumluluk davası açılması engellenmiş olacaktır ${ }^{126} .1933$ tarihli Menkul Kıymetler Kanunu $§ 12$ hükmünde herhangi bir kimse, elindeki menkul kıymeti sattıysa, karşılığında aldığı bedeli düşmek suretiyle o kıymeti satın alırken ödediği bedeli faiziyle birlikte zarar kalemi olarak tazmin edebilir. Buna göre dava açmadan önce menkul kıymet satılmışsa, davacı yatıımcının o menkul kıymeti satın alırken ödediği bedel ve sattığı bedel arasındaki fark; dava açtıktan sonra ancak karar verilmeden önce söz konusu kıymet satıldıysa satın alma bedeli ile sattığı bedel arasındaki fark1; ve son olarak da kararın verilmesi tarihinde hala yatırımcı menkul kıymeti elinde bulunduruyorsa satın alma bedeli ile kararın verildiği tarihte menkul kıymetin değeri arasındaki fark tazminat miktarını oluşturacaktır.

Son olarak kamuyu aydınlatmanın kamusal yarar sağlayan bir uygulama olmasi ${ }^{127}$ dolayısıyla yatırımciların zararının tazmininde, sadece bireysel bazda malvarlığı zararının tazmininin değil kamusal anlamda bu tür hukuka aykırı fiyatların oluşumunu engellemek için caydırıcı tazminatların da öngörülmesi gerekmektedir. Özellikle ülkemizde yatırımcıların hukuka aykırı bilgilendirmeler dolayısıyla şimdiye kadar zararlarının tazminini talep etmedikleri de düşünüldüğünde ${ }^{128}$, hak aramada farkındalığın artırılması, yatırımcıların sorumluluk davası açma konusunda teşvik edilmesi amacıyla hükmedilebilecek tazminat miktarlarının caydırıcı nitelikte olması faydalı olacaktır ${ }^{129}$.

\section{SONUÇ}

SPKn m. 32 hükmünde yer alan kamuyu aydınlatma belgelerinden sorumluluk uyarınca bu belgeleri imzalayan veya bu belgeler kendi adına imzalanan kişilerle izahname açısından SPKn m. 10'da belirtilen kişiler, bu belgelerde yer alan yanlış, yanıltıcı ve eksik bilgilerden kaynaklanan zarardan dolay1 sorumludurlar. SPKn m. 32'de düzenlenen sorumluluk kural olarak kusur sorumluluğudur ve yatırımcı bu hükmün yanı sıra genel hükümlere göre de zararının tazmin edilmesini isteyebilir. Açılacak tazminat davasının konusu, hukuka aykırı açıklamadan dolayı zarar gören yatırımcının zararının tazmini olacaktır. SPKn m. 32 uyarınca kamuyu aydınlatma belgelerinden doğan hukuki sorumluluk borçlar hukukundaki klasik unsurlarına ayrılmak suretiyle bu çalışmada incelenmiştir. Kamuyu aydınlatma belgelerindeki bilgilerin yanlış,

\footnotetext{
126 COFFEE, s. 546.

127 MANAVGAT, (2016), s. 247; Zühtü AYTAÇ, “Anonim Ortaklık Denetçilerinin Sır Saklama Yükümlülüğü’, BATiDER, Cilt 10, 1979, s. 177.

128 TURAN, s. 224.

129 MANAVGAT, (2016), s. 247.
} 
yanıltıcı veya eksik olması sebebiyle gerçeği yansıtmaması yatırımcının zararına sebep olmuşsa, m. 10'da sayılanlar, kamuyu aydınlatma belgelerini imzalayanlar veya bu belgeler kendi adına imzalanan kişilerin kusurlarının bulunması halinde sorumlulukları gündeme gelecektir. Ayrı bir unsur olarak zarar, yatırımcının, kamuyu aydınlatma belgelerindeki bilginin yanlış, yanıltıcı veya eksik olması nedeniyle malvarlığında rızası dışında meydana gelen azalmadır.

Zararın tanımı ve dolayısıyla kapsamının belirlenmesine ilişkin ileri sürülen görüşlerden ilkine göre, yatırımcının yanlış, yanıltıcı veya eksik bilgilerin bulunduğu belgelerin kamuya açıklanması ile yapay fiyattan alım veya satım işlemi yapmış olması, zararın ortaya çıkması için yeterlidir. İkinci görüşe göre yatırımcının ilk alım veya satım işlemini yaptığı yapay fiyat ile düzeltici açıklamadan sonra ortaya çıkan gerçek fiyat arasındaki fark, yatırımıının zararını oluşturmaktadır. Son görüşe göre yatırımcının düzeltici açılamadan sonra ters işlemi yapmasıyla zararın doğacağı ve malvarlığında açıkça meydana gelen farkın zararı oluşturacağı savunulmaktadır. Türk hukukuna genel hükümler uyarınca zarar kavramının tespitinde haksız fiiller için fark görüşünün doktrinde hakim olduğu görülmektedir. Borçlar hukukuna göre zarar, gerçek bilginin kamuya açıklanmasını takiben fiyatların değişmesi ile ters işlem yapılmazsa yapay fiyat ve değişen fiyat arasındaki fark; ters işlem yapılırsa ilk işlemin yapıldığı ve yatırımcı tarafindan ödenen yapay fiyat ve ters işlemin yapıldığı fiyat arasındaki farktan oluşur. SPKn m. 32'deki zararın işlem yapılan yapay fiyat ile hukuka aykırı açıklama yapılmasaydı oluşacak varsayımsal fiyat arasındaki farktan meydana gelmediği; piyasada oluşan gerçek fiyatlar üzerinden hesaplandığı görülmektedir. Dolayısıyla SPKn m. 32/4'te dolaylı olarak belirtildiği üzere sermaye piyasas1 hukukundaki zarar kavramı genel hükümlerdekinden farklıdır ve kapsamı da daha dardır. Nitekim buradaki zarar, SPKn m. 32/4'ten anlaşıldığı üzere yalnızca hukuka aykırı açıklamadan sonra belirli süreler içerisinde alım veya satım işlemlerinin yapılmasının ardından gelen düzeltici açıklama sonucunda ters işlemin yapılmasından doğan zararlardır. Yine de genel hükümler de sermaye piyasasındaki sorumlulukta uygulama alanı bulabilir; eğer kamuyu aydınlatma belgelerinde yanlış, yanıltıcı ve eksik bilgi yer alıyorsa öncelikle SPKn m. 32'nin uygulanması sonra da uygun düştüğü ölçüde genel hükümlerdeki haksız fiil veya sözleşme sorumluluğunun uygulanması söz konusu olacaktır.

Zararın doğduğu ana ilişkin benimsenen ters işlem görüşü, Türk hukukunda tazminatın belirlenmesi açısından bir fark oluşturmasa da; zararın belirlenmesinde önemli bir rol oynamakta ve bu durum da, Türk borçlar hukuku ve sermaye piyasası hukuku arasında bir farklılık doğmaktadır. Zararın hesaplanması 
açısından Türk borçlar hukukundaki hakim görüş uyarınca hakimin karar vereceği tarih esas alınmaktadır; ancak uygulamada Yargitay zararın hesaplanmasında zarar verici olay veya işlemin gerçekleştiği tarihi zararın hesaplanmasında esas almaktadır. Sermaye piyasası hukukunda benimsenen ters işlem görüşü, zararın belirlenmesine ilişkin oldukça net bir zaman dilimi sunmaktadır. Buna göre hukuka aykırı bilgi açıklandıktan sonra ilk işlemin yapıldığı fiyat ile düzeltici açıklamadan sonra ters işlemin yapıldığı fiyat arasındaki fark, SPKn m. 32 uyarınca zararı oluşturur. Sonuç olarak, bu çalışmada SPKn m. 32'ye dayanarak açılacak tazminat davalarında tazmin edilmesi gereken zarar, hukuka aykırı bilgilerin yer aldığı kamuyu aydınlatma belgelerinin açıklanması ile alım veya satım işleminin yapılmasını takiben gelen düzeltici açılama sonrasında yatırımcının ters işlem yaptığı anda doğduğu savunulmuştur.

\section{KAYNAKÇA}

ADIGÜZEL, Burak: Sermaye Piyasası Hukuku, 2. Baskı, Adalet, Ankara, 2018.

ARGANBRIGHT, John: "No Loss, No Problem: How the Second Circuit Altered Dura and the Concept of Economic Loss in Securities Fraud Cases in Acticon AG v. China North East Petroleum Holdings, Ltd.", Seton Hall Law Review, Cilt. 44, 2014, ss. 279-304.

AYAN, Mehmet: Borçlar Hukuku (Genel Hükümler), 10. Baskı, Mimoza, Ankara, 2015.

AYOĞLU, Tolga: Sermaye Piyasası Hukukunda Halka Arz Kavramı ve Halka Arza Aracılık Sözleşmeleri, Vedat, İstanbul, 2008.

AYTAÇ, Zühtü: “Anonim Ortaklık Denetçilerinin Sır Saklama Yükümlülüğü̈, BATIDER, Cilt 10, 1979, ss. 177-218.

CHAMBLEE BURCH, Elizabeth: "Reassesing Damages in Securities Fraud Class Actions" Maryland Law Review, Cilt 66, S. 2, ss. 348-397.

COFFEE, John C.: "Causation By Presumption? Why the Supreme Court Should Reject Phantom Losses and Reverse Broudo?" Columbia Law and Economics Working Paper, No. 264, 2005.

ÇATAKOĞLU, Buket: "Halka Arzda İzahnamenin Hukuki Niteliği ve İzahnameden Doğan Hukuki Sorumluluk," Kastamonu Üniversitesi İiBFD, S. 11, 2016, ss. $118-132$. 
ÇETIN, Nusret/ TÖREMIŞ, Hatice Ebru/ CANTIMUR, Zeynep: 6362 Sayılı Sermaye Piyasası Kanunu'nun Sistematik Analizi, Yetkin, Ankara, 2014.

EREN, Fikret: Borçlar Hukuku Genel Hükümler, 21. Baskı, Yetkin, Ankara, 2017.

FENCHER, Marvin/ TIPTON, Travis: "Securities Regulation in Germany and the US," Comparative Corporate Governance and Financial Regulation, Select Seminar Paper 5, 2016.

FISCHEL, Daniel R.: "Efficient Capital Markets, the Crash and the Fraud on the Market Theory," Cornell Law Review, Cilt 74, 1989, ss. 907-922.

FOX, Merritt: "Demystifying Causation in Fraud-on-the Market Actions," The Business Lawyer, Cilt 60, 2005, ss. 507-532.

GÜNDOĞDU, Aysel: 6362 Sayılı Sermaye Piyasası Kanunu'na Göre Türkiye'de Sermaye Piyasasının Değişen Yüzü, Seçkin, Ankara, 2015.

HORWICH, Allan: "Section 11 of the Securities Act: The Cornerstone Needs Some Tuckpointing" The Business Lawyer, Cilt 58, S. 1, 2002, ss. 1-43.

İHTIYAR, Mustafa: Sermaye Piyasası Hukukunda Kamuyu Aydınlatma İlkesi, Beta, İstanbul, 2006.

INAL, Tamer: Borca Aykırılık, Dönme ve Fesih, 6. Baskı, Seçkin, Ankara, 2017.

İNCEOĞLU, Mehmet Murat: Sermaye Piyasasında Aracı Kurumların Hukuk Sorumluluğu, Seçkin, Ankara, 2004.

KARA, Mustafa Sencer: "Kamuyu Aydınlatma Belgelerinden Doğan Hukuki Sorumluluk," Gazi Üniversitesi Hukuk Fakültesi Dergisi, Cilt 23, S. 2, 2015, ss. 131- 172.

KARABABA, Serdar: Hisse Senedi Yatırımcısının Korunması, Seçkin, Ankara, 2001.

KHOO, Joanna: "Civil Liability For Misstatements in Offer Documents: Striking the Right Balance," BYU International Law and Management Review, Cilt 6, S. 2, 2010, ss. 49-91.

KESKIN, Mustafa: Halka Açık Anonim Ortaklıkların Kamuyu Aydınlatma Yükümlülüğü, Oniki Levha, İstanbul, 2018.

KILIÇOĞLU, Ahmet M.: Borçlar Hukuku Genel Hükümler, 21. Bası, Turhan, Ankara, 2017.

KOÇHISARLIOĞLU, Cengiz: “Objektif Sorumluluğun Genel Teorisi” Dicle 
Türk ve ABD Hukukunda Kamuyu Aydınlatma Belgelerinden Doğan Hukuki...

Üniversitesi Hukuk Fakültesi Dergisi, Cilt 2, Say1 2, 1984, ss. 175-305. KÜTÜKÇÜ, Doğan: Sermaye Piyasası Hukuku, 1. Cilt, Beta, İstanbul, 2004.

LANGEVOORT, Donald C.: "Deconstructing Section 11: Public Offering Liability in a Continuous Disclosure Environment," Law and Contemp. Probs. Cilt. 63, 2000, ss. 45-70.

MANAVGAT, Çağlar: "Bilgiye Dayalı Manipülasyonda Menfaat Elde Etme Şartının Yerindeliği”, BATIDER, C. XXXIII, S. 2, 2017, ss. 29-41.

MANAVGAT, Çağlar: Hukuki Bakımdan Halka Açık Anonim Ortaklıkla ve Halka Arz, Banka ve Ticaret Hukuku Araştırma Enstitüsü, Ankara, 2016.

NICHOLLS, Christopher C.: "Civil Enforcement in Canadian Securities Law", Journal of Corporate Law Studies, Cilt 9, S. 2, 2009, ss. 367-408.

NIELSEN, Peri/ PROWSE, Stephen: "Securities Litigation: Dura's Impact on Damages" Insights, Cilt 22, S. 7, 2008, ss. 16-25.

NOMER, Haluk: Haksız Fiil Sorumluluğunda Maddi Tazminatın Belirlenmesi, İstanbul 1996.

OĞUZMAN, Kemal/ ÖZ, Turgut M.: Borçlar Hukuku Genel Hükümler, Cilt I, 14. Bask1, Vedat, İstanbul 2016.

OĞUZMAN, Kemal/ ÖZ, Turgut M.: Borçlar Hukuku Genel Hükümler, Cilt II, 12. Bask1, Vedat, İstanbul 2016.

SIMMONDS, Andrew R./ SAGAT, Kenneth A./ RONEN, Joshua: "Dealing With Anomalies, Confusion and Contradiction in Fraud on the Market Securities Class Actions", Kentucky Law Journal, Cilt 81, 1992-93, ss. 123-186.

TANDOĞAN, Haluk: Türk Mes'uliyet Hukuku, 2. Baskı., Vedat, İstanbul 2010. TANÖR, Reha: Türk Sermaye Piyasası: Taraflar, 1. Cilt, Beta, İstanbul 1999.

TEKINALP, Ünal: Sermaye Piyasası Hukukunun Esasları, Ekonomik ve Sosyal Yayınlar, İstanbul 1982.

TEKINAY, Selahattin Sulhi/ AKMAN, Sermet/ BURCUOĞLU, Haluk/ ALTOP, Atilla: Borçlar Hukuku Genel Hükümler, 6. Bask1, Filiz Kitapevi, İstanbul 1988.

TURAN, Gökçen: "Türk Hukukunda İzahnameden Doğan Hukuki Sorumluluğun Esaslarn," Gazi Üniversitesi Hukuk Fakültesi Dergisi, C. XX, S. 1, 2016, ss. 191-231. 